\title{
Fernanda Appolonio
}

Estudo experimental comparativo de implantes arteriais politetrafluoretileno expandido (PTFE) versus polidimetilsiloxano com reforço de tecido de poliéster

Tese apresentada à Faculdade de Medicina da Universidade de São Paulo para obtenção do título de Doutor em Ciências

Programa de: Clínica Cirúrgica

Orientador: Prof. Dr. Nelson De Luccia

São Paulo 
Dados Internacionais de Catalogação na Publicação (CIP)

Preparada pela Biblioteca da

Faculdade de Medicina da Universidade de São Paulo

Creprodução autorizada pelo autor

\section{Appolonio, Fernanda}

Estudo experimental comparativo de implantes arteriais : politetrafluoretileno expandido (PTFE) versus polidimetilsiloxano com reforço de tecido de poliéster / Fernanda Appolonio. -- São Paulo, 2014.

Tese(doutorado)--Faculdade de Medicina da Universidade de São Paulo.

Programa de Clínica Cirúrgica.

Orientador: Nelson De Luccia.

Descritores: 1.Prótese vascular 2.Dimetilpolisiloxanos 3.Silicones 4.Poliésteres 5.Politetrafluoretileno 6.Aorta abdominal/cirurgia 7.Coelhos 8.Implantes experimentais 9.Estudo comparativo

USP/FM/DBD-084/14 
Este trabalho foi desenvolvido no Laboratório de Pesquisa em Cirurgia Experimental do Departamento de Cirurgia da Faculdade de Medicina da USP (LIM-26).

O projeto de pesquisa foi aprovado na Comissão de Ética pela Análise de Projetos (CAPPesq), da Diretoria Clínica do Hospital das Clínicas da Faculdade de Medicina da Universidade de São Paulo, em sessão de 05/08/2009 sob número 0716/09. 
O convívio com pacientes portadores de isquemia de membros inferiores é extremamente marcante para os cirurgiões vasculares. Tal experiência nos estimula a pensar, pesquisar e tentar buscar soluções para dificuldades e desafios encontrados no dia a dia da especialidade. A esses pacientes, meu respeito e dedicação.

Aos meus pais, Cleide e José Ricardo, pelo amor incondicional e pela vida dedicada aos filhos.

Ao Milton, meu esposo, por seu apoio e seu estímulo. Sua presença ao meu lado é imprescindível, sempre.

Ao João Guilherme, meu filho, por me fazer uma pessoa melhor e mais feliz todos os dias e por ter me ensinado o verdadeiro sentido da vida. 


\section{AGRADECIMENTOS}

Ao Prof. Dr. Nelson De Luccia, exemplo como pessoa, professor e médico. Sua inteligência e seu espírito incansável na busca por novas idéias e soluções são contagiantes. Seus ensinamentos para minha vida pessoal e profissional serão levados para sempre.

À Laila Massad Ribas, médica veterinária, pela amizade antes de tudo, e pelas inestimáveis colaboração, dedicação e organização, sem as quais esse trabalho não haveria sido realizado.

Ao Paulo Isao Sassaki Neto pelas ótimas ideias, pelo tempo dedicado à minha tese, pelas sugestões e pela ajuda na interpretação dos dados.

À Karina Paula Domingos Rosa Schneidwind por sua dedicação a esse projeto, pelo estímulo e pela ajuda nos procedimentos cirúrgicos.

À Marina Artimonte Farjallat pela amizade e por ter me convidado a participar dessa linha de pesquisa quando ainda era um pequeno embrião.

À Creusa Maria Roveri Dal Bó pela atenção e cuidado na análise estatística.

À Sra. Junko Takano Osaka e aos funcionários do Laboratório de Técnica Cirúrgica, Cláudio Antonio Vidotti, Ourisval Santana Santos e Elias Aparecido Marcelino, pela presença, incentivo e ajuda fundamentais semana a semana, e também pelo respeito e cuidados com os animais.

Ao Ezequiel Sampaio da Silva e ao Renato Dias da Silva pela produção das próteses e pelos cuidados pós-operatórios dos animais.

Mais uma vez à minha mãe pela ajuda inestimável na correção, formatação e finalização desta tese. 
"Você vê as coisas como são e diz 'Por quê?' Mas eu sonho com as coisas que nunca foram e digo 'Por que não?'”

You see things and you say 'Why?' But I dream things that never were and I say 'Why not?'

George Bernard Shaw

"Back to Methuselah" (1921), part 1, act 1 
Esta tese está de acordo com as seguintes normas, em vigor no momento desta publicação:

Referências: adaptado de International Committee of Medical Journals Editors (Vancouver)

Universidade de São Paulo. Faculdade de Medicina. Divisão de Biblioteca e Documentação. Guia de apresentação de dissertações, teses e monografias. Elaborado por Anneliese Carneiro da Cunha, Maria Julia de A. L. Freddi, Maria F. Crestana, Marinalva de Souza Aragão, Suely Campos Cardoso, Valéria Vilhena. $3^{a}$. ed. São Paulo: Divisão de Biblioteca e Documentação; 2011.

Abreviatura dos títulos dos periódicos de acordo com List of Journals Indexed in Index Medicus. 


\section{SUMÁRIO}

Lista de abreviaturas

Lista de símbolos

Lista de figuras

Lista de tabelas

Lista de gráficos

Resumo

Summary

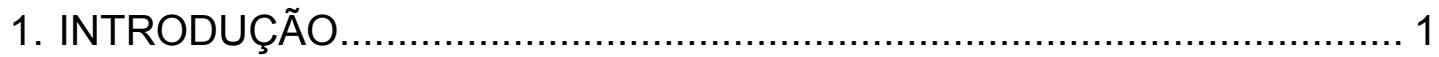

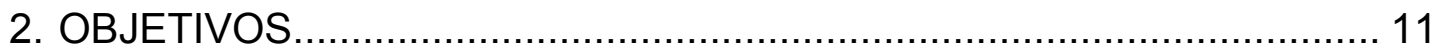

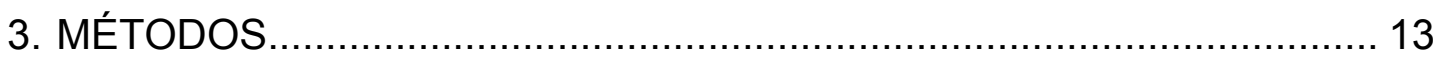

3.1 Animal de Experimentação ................................................ 14

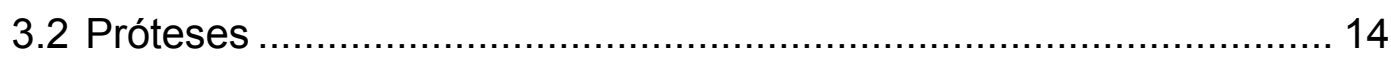

3.3 Plano Experimental ............................................................... 16

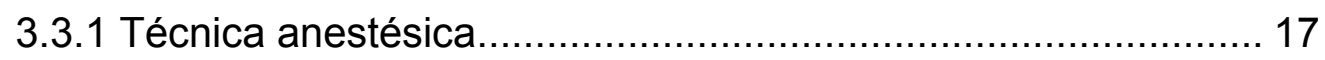

3.3.2 Técnica cirúrgica ................................................. 18

3.3.3 Período pós-operatório............................................. 23

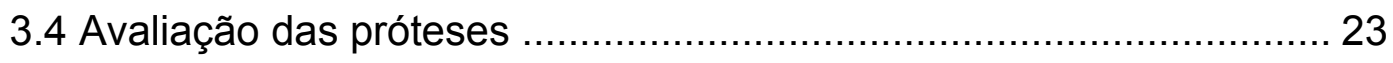

3.5 Análise estatística ................................................................... 26

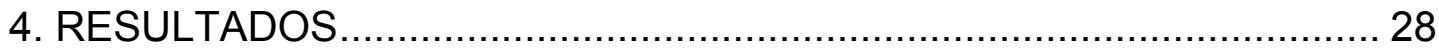

4.1 Evolução clínica e complicações pós-operatórias ........................... 29

4.1.1 Mortalidade ................................................................ 30

4.1.2 Paraplegia .......................................................... 31

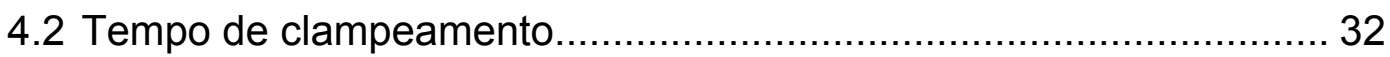

4.2.1 Tempo de clampeamento e complicações............................... 33

4.2.1.1 Tempo de clampeamento e paraplegia ...................... 34

4.2.1.2 Tempo de clampeamento e óbitos ............................. 36

4.2.2 Tempo de clampeamento e patência das próteses ................ 37

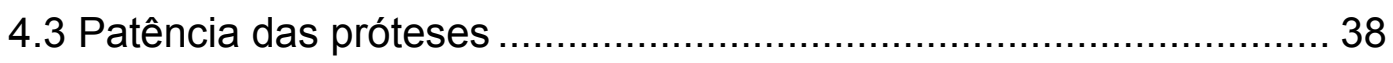


4.4 Grau de estenose das próteses patentes. 45

4.5 Análise do implante das próteses................................................. 49

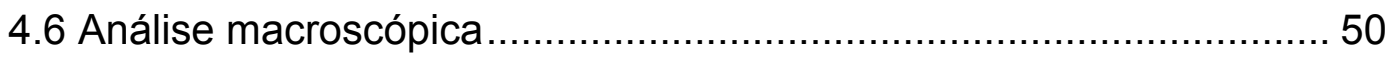

4.7 Microscopia eletrônica .............................................................. 52

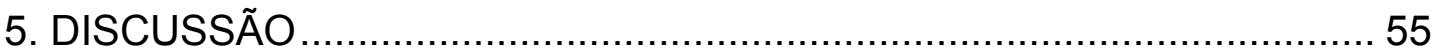

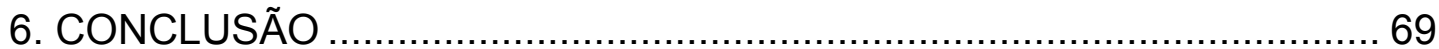

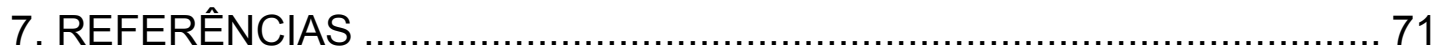


LISTA DE ABREVIATURAS

$\begin{array}{ll}\text { PTFE } & \text { Politetrafluoretileno expandido } \\ \text { PDMS } & \text { Polidimetilsiloxano } \\ \mathrm{HCl} & \text { Cloreto de hidrogênio (ácido clorídrico) } \\ \mathrm{n} & \text { Número }\end{array}$




\section{LISTA DE SÍMBOLOS}

$\begin{array}{ll}\% & \text { por cento } \\ < & \text { menor } \\ = & \text { maior } \\ \circledR & \text { igual } \\ \mathrm{mm} & \text { marca registrada comercial } \\ \mathrm{cm} & \text { milímetro } \\ \mu \mathrm{m} & \text { centímetro } \\ \mathrm{g} & \text { micrômetro } \\ \mathrm{mg} & \text { grama } \\ \mathrm{kg} & \text { quiligrama } \\ \mathrm{G} & \text { gauge } \\ \mathrm{L} & \text { litro } \\ \mathrm{mL} & \text { mililitro } \\ \mathrm{min} & \text { minuto } \\ \mathrm{UI} & \text { unidade internacional }\end{array}$




\section{LISTA DE FIGURAS}

Figura 1 - Estrutura química do polidimetilsiloxano (PDMS) ………........ 8

Figura 2 - Ilustração da prótese de PDMS .............................................. 15

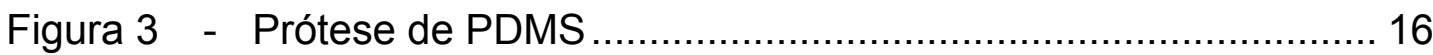

Figura 4 - llustração do animal com aorta abdominal dissecada e

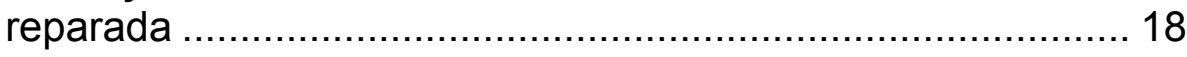

Figura 5 - Aorta dissecada, clampeada e aberta (arteriotomia

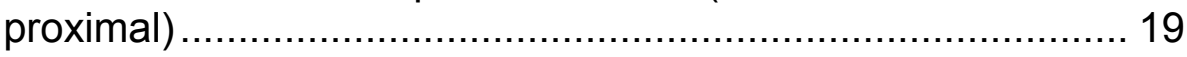

Figura 6 - Prótese de PDMS implantada …………………………..... 20

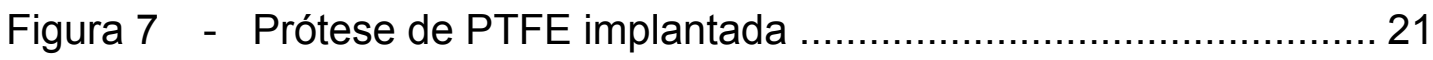

Figura 8 - Tempo principal do implante cirúrgico das próteses ……….... 22

Figura 9 - Artéria femoral dissecada e cateterizada para realização da arteriografia; cateter visualizado à fluoroscopia ................. 24

Figura 10 - Angiografia da aorta de coelho na qual foi implantado enxerto de PDMS - $30^{\circ}$ dia pós-operatório.............................. 25

Figura 11 - Angiografia da aorta após 70 dias do implante de prótese de PTFE (prótese patente)

Figura 12 - Angiografia após 82 dias do implante de prótese de PDMS (prótese patente)

Figura 13 - Angiografia após 76 dias do implante de prótese de PDMS, com oclusão da mesma e circulação colateral exuberante ..... 40

Figura 14 - Angiografia da aorta após 78 dias do implante de prótese de PDMS, sem estenoses.

Figura 15 - Angiografia da aorta após 55 dias do implante de prótese de PDMS, com estenose de $23 \%$ na anastomose proximal ... 46

Figura 16 - Angiografia da aorta após 79 dias do implante de prótese de PDMS, com estenose de 50\% nas anastomoses proximal e distal.

Figura 17 - Angiografia da aorta após 80 dias do implante de prótese de PTFE, apresentando estenose de $10 \%$ na anastomose proximal 
Figura 18 - Angiografia da aorta após 90 dias do implante de prótese de PTFE, sem estenoses

Figura 19 - Angiografia da aorta após 70 dias do implante de prótese de PTFE, estenose estimada de $25 \%$ na anastomose distal .. 48

Figura 20 - Secção longitudinal da anastomose proximal da prótese de PDMS (notar neoíntima na região da linha de sutura) ....... 51

Figura 21 - Secção longitudinal da anastomose proximal da prótese de PTFE (notar neoíntima na região da linha de sutura)

Figura 22 - Aspecto da microscopia eletrônica da prótese de PDMS recoberta pela neoíntima na região da anastomose

Figura 23 - Aspecto da microscopia eletrônica da prótese de PTFE recoberta pela neoíntima em região próxima à anastomose .. 53

Figura 24 - Região da anastomose com prótese de PTFE (observar o fio de sutura e toda região anastomótica recoberta)

Figura 25 - Microscopia eletrônica da região onde ocorre o final da progressão do endotélio (notar no quadrante superior esquerdo a prótese de PDMS não recoberta)

Figura 26 - Linha de sutura da prótese de PDMS após 82 dias do implante, com crescimento exuberante do endotélio junto à região da anastomose (hiperplasia intimal) 


\section{LISTA DE TABELAS}

Tabela 1 - Evolução pós-operatória dos animais por grupo ....................... 29

Tabela 2 - Tempo de clampeamento (em minutos) .............................. 32

Tabela 3 - Tempo de clampeamento e complicações ................................ 33

Tabela 4 - Tempo de clampeamento e paraplegia ................................ 34

Tabela 5 - Tempo de clampeamento e óbitos …...................................... 36

Tabela 6 - Tempo de clampeamento e patência das próteses.................... 37

Tabela 7 - Resumo dos dados da análise pelo método de Kaplan Meier .... 41

Tabela 8 - Patência do grupo PDMS-Sobrevida na condição patente......... 42

Tabela 9 - Patência do grupo PTFE - Sobrevida na condição patente.......... 43 


\section{LISTA DE GRÁFICOS}

Gráfico 1 - Evolução pós-operatória dos animais por grupo..................... 30

Gráfico 2 - Relação entre mortalidade e prótese utilizada ........................ 31

Gráfico 3 - Tempo de clampeamento e complicações............................... 34

Gráfico 4 - Tempo de clampeamento e paraplegia................................ 35

Gráfico 5 - Tempo de clampeamento e óbito........................................... 37

Gráfico 6 - Tempo de clampeamento e patência.................................... 38

Gráfico 7 - Curvas de patência de Kaplan Meier .................................. 44

Gráfico 8 - Risco de oclusão estimado ................................................. 44

Gráfico 9 - Grau de estenose..................................................... 49 


\section{RESUMO}

APPOLONIO F. Estudo experimental comparativo de implantes arteriais politetrafluoretileno expandido (PTFE) versus polidimetilsiloxano com reforço de tecido de poliéster.[tese]. São Paulo: Faculdade de Medicina, Universidade de São Paulo; 2014.

INTRODUÇÃO: Os enxertos vasculares sintéticos disponíveis atualmente apresentam baixos índices de patência, quando utilizados na revascularização de vasos de pequeno calibre, e possuem resultados inferiores quando comparados ao uso de veias autólogas em derivações infrageniculares. Nova prótese de pequeno calibre confeccionada em silicone (polidimetilsiloxano, PDMS) com reforço de tecido de poliéster foi desenvolvida e comparada à prótese de PTFE. OBJETIVOS: Analisar, em modelo experimental em coelhos, o tubo de PDMS como material para prótese vascular e compará-lo a prótese de PTFE. MÉTODOS: Quarenta coelhos foram submetidos a interposição na aorta infrarrenal de próteses de $4 \mathrm{~mm}$ de diâmetro, sendo 20 animais com PDMS e 20 com PTFE (grupo controle). Foi medido o tempo de clampeamento e realizada arteriografia retrógrada da aorta para avaliar a patência das próteses. Para avaliar a endotelização das próteses foi realizada microscopia eletrônica de maneira amostral pareada. RESULTADOS: Vinte e cinco animais (62,5\%) não apresentaram intercorrências pós-operatórias; oito (20\%) morreram precocemente e sete $(17,5 \%)$ ficaram paraplégicos no pós-operatório imediato (e foram sacrificados), sendo que esses animais não foram incluídos nas análises de patência. Não foi observada diferença entre os grupos quanto à evolução com complicações pós-operatórias $(p=0,526)$ e quanto ao tempo de clampeamento da aorta $(p=0,299)$. A patência em 30 dias foi de $100 \%$ para as duas próteses. Aos 60 dias, a taxa de patência do PDMS foi de $92,3 \%( \pm 7,4)$, e de $73,8 \%( \pm 13,1)$ em 90 dias; as próteses de PTFE tiveram taxas de patência de $87,5 \%( \pm 11,7)$ aos 60 e 90 dias. Não foi observada diferença significativa entre as taxas de patência dos grupos $(p=0,62)$. Não houve diferença siginificativa entre os grupos quanto ao grau de estenose das próteses patentes $(p=0,650)$ à avaliação angiográfica. A microscopia eletrônica mostrou crescimento endotelial limitado às regiões próximas às anastomoses nos dois tipos de próteses. CONCLUSÃO: O PDMS mostrou-se passível de utilização como prótese vascular, com resultados comparáveis aos do PTFE no modelo utilizado.

Descritores: Prótese vascular; Dimetilpolisiloxanos; Silicones; Poliésteres; Politetrafluoretileno; Aorta abdominal/cirurgia; Coelhos; Implantes Experimentais; Estudo comparativo. 


\section{SUMMARY}

APPOLONIO F. Experimental comparative study of arterial implants expanded polytetrafluoroethylene (PTFE) versus dimethylpolysiloxane reinforced with polyester fabric [thesis]. São Paulo: Faculdade de Medicina, Universidade de São Paulo; 2014.

INTRODUCTION: Synthetic vascular grafts currently available have suboptimal patency rates in small-diameter vessels and inferior outcomes in below-the-knee arterial bypass procedures when compared to the use of autologous vein. A new small vessel prosthesis made of silicone (polydimethylsiloxane, PDMS) and reinforced with polyester fabric was developed and compared to the standard PTFE prosthesis. OBJECTIVES: On a rabbit experimental model, we compared the outcomes of new PDMS vascular prostheses with PTFE vascular prostheses. METHODS: Forty rabbits underwent infra-renal aorta replacement with $4 \mathrm{~mm}$ diameter prostheses, twenty animals with PDMS and twenty animals with PTFE (control group). Aortic clamping time was measured and retrograde aortic angiography was performed to assess patency. Histological graft samples were examined by electron microscopy to evaluate prostheses endothelialization. RESULTS: Twenty-five $(62,5 \%)$ animals had good surgical outcome; eight animals (20\%) expired and seven animals (17.5\%) became paraplegic (and subsequently sacrificed) during early follow up and were not included in anastomosis patency analysis. Postoperative complications (death, paraplegia) rates $(p=0,526)$ and aortic clamping times $(p=0,299)$ were comparable in both groups. Patency rates in 30 days were $100 \%$ for both grafts. At 60 days, patency rate for PDMS was $92,3 \%( \pm 7,4)$, and $73,8 \%$ $( \pm 13,1)$ at 90 days. PTFE grafts had patency rates of $87,5 \%( \pm 11,7)$ at 60 and 90 days. No statistically significant difference was found in between groups for patency rates $(p=0,62)$. No statistically significant difference for stenosis was found on angiographical analysis in between groups $(p=0,650)$. Electron microscopy revealed limited anastomotic endothelial ingrowth in both prostheses used. CONCLUSION: In this experimental model, PDMS and PTFE vascular prostheses had comparable outcomes and PDMS prosthesis could be used as a vacular graft.

Descriptors: Blood vessel prosthesis, Dimethylpolysiloxanes, Silicones, Polyesters, Polytetrafluoroethylene, Aorta, abdominal/surgery, Rabbits, Implants, experimental, Comparative Study. 
1. INTRODUÇÃO 
Doenças que acometem os vasos sanguíneos, principalmente as artérias de pequeno calibre (diâmetro $<6 \mathrm{~mm}$ ), são a principal causa de mortalidade nos Estados Unidos e demais países ocidentais. Quando acometidos por doenças como a aterosclerose, os vasos podem evoluir para estenose e oclusão, levando à redução do fluxo sanguíneo e danos teciduais. São exemplos o infarto do miocárdio por oclusão das artérias coronárias, claudicação e isquemia crítica de membros inferiores por doença arterial periférica, e acidentes vasculares cerebrais isquêmicos devido ao acometimento das artérias carótidas ${ }^{1}$.

Para o tratamento cirúrgico da doença arterial, os enxertos são uma das alternativas mais utilizadas, sendo realizadas, a cada ano, mais de 1,4 milhão de revascularizações em ponte (coronariana e periférica), somente nos Estados Unidos ${ }^{1}$, e cerca de três vezes esse valor no mundo todo ${ }^{2}$. Nos procedimentos de revascularização arterial, são utilizados substitutos vasculares e os preferidos atualmente pelos cirurgiões são as veias autólogas (preferencialmente a veia safena interna) ou, em alguns casos, artérias autólogas (como mamária e radial).

O desenvolvimento do substituto arterial ideal é comparado à busca pelo "Santo Graal" por alguns autores ${ }^{3-5}$. Tal substituto deveria reunir uma série de propriedades: baixa trombogenicidade, elevada biocompatibilidade (especialmente com o sangue), bioestabilidade, ausência de toxicidade, complacência semelhante à do vaso ao qual vai ser suturado, facilidade de manuseio e sutura, resistência ao desenvolvimento de hiperplasia intimal e 
infecções, durabilidade a longo prazo, disponibilidade em vários diâmetros e comprimentos, facilidade de produção e armazenamento, baixo custo ${ }^{3,6,7}$.

Devido às características destacadas para que um substituto arterial seja considerado ideal, é possível entender o porquê das artérias nativas serem descritas como a melhor opção para uma revascularização ${ }^{7}$. Em muitos casos porém, não há nenhum segmento arterial autólogo com diâmetro e extensão suficientes para serem usados numa cirurgia em ponte, especialmente em revascularizações distais do membro inferior e em reconstruções de vasos de grande calibre, como em uma correção de aneurisma da aorta. Nas revascularizações coronarianas, é frequente o uso das artérias mamária e radial, além da veia safena magna. Para as revascularizações de membros inferiores, a veia safena autóloga é considerada o substituto arterial de escolha. Infelizmente uma grande parte dos pacientes com indicação de cirurgia de revascularização não possui substitutos autólogos para serem usados nesses procedimentos, havendo necessidade de se recorrer a enxertos sintéticos ${ }^{8,9}$.

O início da pesquisa de próteses vasculares data da década de 40 , quando Hufnage ${ }^{10}$, Donovan e Zimmerman ${ }^{11}$, e Moore ${ }^{12}$ testaram próteses de metilacrilato e polietileno na aorta de modelos animais. Polímeros sintéticos como o Nylon, logo substituído pelo Dacron, são utilizados há mais de 60 anos como enxertos vasculares. No início, esses tecidos eram costurados artesanalmente para adquirir estrutura tubular ${ }^{13}$. 
O uso rotineiro de próteses vasculares foi muito impulsionado pelo trabalho de Voorhees, que trabalhava com Blakemore na Universidade de Columbia, nos Estados Unidos. Notou-se que o fio de seda que havia permanecido por longo período de tempo no ventrículo direito de um dos cães do laboratório, tornou-se revestido por superfície brilhante, nacarada, semelhante à endotelial. Fios de outros materiais sintéticos como Vinyon"N", usados em velas de embarcações, também se tornavam revestidos por este filme macio, brilhante e livre de trombos macroscópicos ${ }^{14}$. O relato de Voorhees e Blakemore em 1954, da substituição de 17 aneurismas de aorta abdominal e um aneurisma de poplítea pelo implante de tubo sintético, foi o início da atual cirurgia arterial reconstrutiva. Entretanto, apesar do enorme avanço em novos materiais daquela época até o momento atual, há 60 anos apenas dois substitutos vasculares sintéticos são usados regularmente em reconstruções arteriais: os polímeros do poliéster (marca de fabricação Dacron) e os polímeros do polietileno (marca de fabricação - Teflon®), na versão expandida por extrusão, conhecida como PTFE (politetrafluoretileno expandido $)^{9,15-17}$.

Além da busca pelo funcionamento dos enxertos como condutores do sangue, procurava-se reproduzir a experiência inicial do revestimento endotelial, que ocorria sobre os fios sintéticos. Até então, experimentos isolados com tubos sólidos de metal, vidro ou borracha mostraram evolução com oclusão precoce ${ }^{18}$. 
Com o aumento da experiência, tornou-se evidente que os enxertos sintéticos funcionavam satisfatoriamente por longos períodos de tempo em artérias de grande calibre, alto fluxo e situações de baixa resistência. No território femoropoplíteo, para as reconstruções acima do joelho, os substitutos sintéticos de dacron ou PTFE, têm resultados semelhantes entre $\mathrm{si}^{13,19} \mathrm{e}$, em algumas séries, até comparáveis aos da veia safena ${ }^{9,18,20-23}$. Entretanto, dois problemas permaneciam: em nenhuma das próteses, a despeito da porosidade, o endotélio progredia além de poucos centímetros da linha de sutura; e as mesmas não funcionavam em áreas de alta resistência e baixo fluxo e em vasos com diâmetro de $4 \mathrm{~mm}$ ou menos ${ }^{16,24,25}$.

Para a reconstrução de artérias menores, como coronárias, fibulares e tibiais, as atuais próteses vasculares são inadequadas. A utilização da veia safena como substituto arterial para calibres de 3 a $6 \mathrm{~mm}$, como é o caso das derivações em ponte para as obstruções arteriais nesses territórios, é consensual $^{17,26,27}$.

O PTFE surgiu como opção de enxerto vascular em 1972, em modelo experimental em porcos ${ }^{28}$. Trata-se de um membro da classe dos polímeros de fluorocarbono, que é apresentado em duas versões para uso como implante protético: têxtil e expandido. A versão expandida é produzida por extrusão e pode ter sua porosidade controlada no processo de produção ${ }^{15}$. Trata-se da versão mais utilizada atualmente.

A patência primária do PTFE para artérias de pequeno calibre distais à poplítea, referida como de $45 \%$ e $25 \%$ aos 2 e 5 anos respectivamente, é 
considerada baixa ${ }^{9}$, apesar de ainda aceitável, se considerarmos as características desta população de arteriopatas graves sem substituto autógeno. Devido às suas limitações (baixas taxas de patência, elasticidade reduzida, baixa complacência e paredes mais resistentes à passagem da agulha $)^{29}$, em geral utiliza-se esse tipo de prótese com algum tipo de manobra técnica adicional, como a interposição de segmento de veia ${ }^{30}$ ou a criação de fístula arteriovenosa distal ${ }^{31}$.

Diante desse cenário, o contingente de outras veias superficiais constitui-se no substituto de escolha, quando da impossibilidade de utilização da veia safena magna homolateral ao membro isquêmico que se objetiva tratar. A veia safena magna contralateral, a veia safena parva, homo ou contralateral, segmentos remanescentes da veia safena magna na região de sua croça ou perto do maléolo, e veias do membro superior, são as opções mais habitualmente utilizadas ${ }^{26,32-35}$. Veias do sistema venoso profundo $^{36}$ ou artérias endarterectomizadas, particularmente a femoral superficial ${ }^{37}$, também são utilizadas como recurso de substitutos vasculares autógenos.

Devido ao fato do PTFE ainda não representar opção considerada satisfatória como substituto protético no território infragenicular, materiais biológicos não autógenos são opções pesquisadas. Veias obtidas de cadáveres representam uma dessas opções. Trata-se de um transplante e, portanto, depende de esquemas de preservação, para que possa ser mantida em bancos para utilização e eliminação da antigenicidade. Os 
métodos mais utilizados são a criopreservação e a preservação em glutaraldeído. Apesar da utilização da safena homóloga ser teoricamente atraente, os resultados com seu uso são semelhantes aos de outros substitutos sintéticos, quando comparados aos resultados de excelência atingidos pela safena autóloga ${ }^{29,38}$.

Outro material biológico homólogo descrito é a veia de cordão umbilical tratada com glutaraldeído. Problemas de dilatação destes enxertos na experiência inicial ${ }^{39}$, tendência à degeneração parietal com o passar do tempo e dificuldades nas anastomoses em artérias de pequeno calibre ${ }^{40}$, foram motivos de desencorajamento de seu uso, além de serem alcançadas patências apenas ligeiramente superiores aos de outros materiais ${ }^{41}$.

O silicone tem larga utilização na prática médica. Seu uso em estruturas tubulares para condução de soluções endovenosas em vários tipos de cateteres, além de próteses, como mamária e peniana, é consagrado. Trata-se de material inerte, o que constitui uma de suas vantagens para utilização em implantes. O silicone possui também bioestabilidade, baixa toxicidade e, sob o ponto de vista de condução do fluxo sanguíneo, baixa trombogenicidade ${ }^{25,42-50}$.

Quanto às próteses vasculares, o uso do silicone foi iniciado para o revestimento de próteses já conhecidas, como o Dacron ${ }^{51}$. Sabe-se que com o silicone é possível obter um revestimento luminal liso, sem polaridade e hidrofóbico. Estas condições, em estudos feitos com consumo de plaquetas marcadas por isótopos radioativos, mostraram-se bem menos trombogênicas do que a de outros polímeros de poliuretano, polares e 
hidrófilos ${ }^{46}$. Entretanto, seu uso como prótese arterial, apesar de referido em algumas publicações experimentais, ainda não atingiu o estágio de utilização clínica rotineira ${ }^{51-60}$.

Os polímeros do dimetilsiloxano (silicone), mais precisamente chamados de siloxanos polimerizados ou polisiloxanos, são misturas de

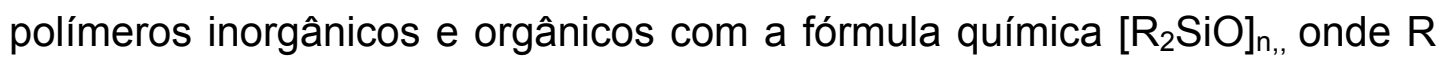
representa grupos orgânicos como metil, etil e fenil. Tais polímeros são constituídos por uma matriz siloxano (Si-O), e os grupos orgânicos laterais ligam-se aos átomos de silício $^{60-62}$ (Figura1).

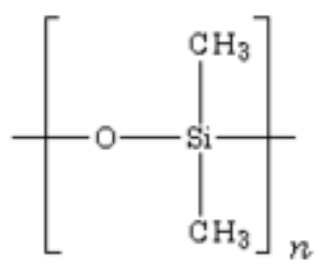

Figura 1 - Estrutura química do polidimetilsiloxano (PDMS).

Em alguns casos, os grupos orgânicos laterais podem ser usados para ligar duas ou mais destas estruturas [-Si-O-]. Pela variação do comprimento das cadeias, grupos laterais e crosslinking, silicones podem ser sintetizados em larga variedade de composições e propriedades. Podem variar em consistência, desde forma líquida, passando por gel, borracha e até plástico duro. O siloxano mais comum é o polidimetilsiloxano linear $\left(\right.$ PDMS) ${ }^{60}$. 
O PDMS é sintetizado a partir de dimetilclorosilano, que reage com água da seguinte forma:

$$
\mathrm{n}\left[\mathrm{Si}\left(\mathrm{CH}_{3}\right)_{2} \mathrm{Cl}_{2}\right]+\mathrm{n}\left[\mathrm{H}_{2} \mathrm{O}\right] \rightarrow\left[\mathrm{Si}\left(\mathrm{CH}_{3}\right)_{2} \mathrm{O}\right]_{\mathrm{n}}+2 \mathrm{n} \mathrm{HCl}
$$

Para uso médico, e evitar a produção de $\mathrm{HCl}$ potencialmente nocivo, os átomos de cloro do precursor silano são substituídos por grupos acetato, levando, no final do processo de cura, à produção do atóxico ácido acético. Entretanto, o processo de cura passa a ser mais lento quando é feita tal substituição ${ }^{62,63}$.

Algumas características físicas talvez expliquem o motivo de 0 silicone ainda não ter aceitação como prótese vascular implantável. Comparado a outros tipos de polímeros, o silicone é o que possui menor estiramento e menor força tênsil e, portanto, menor facilidade de manuseio e de aceitação a suturas. Portanto, a menor força tênsil e suscetibilidade ao rasgo, tornariam estruturas tubulares em silicone menos adequadas a suturas.

Em formulações que conferem maior resistência aos tubos de silicone, a dureza final as torna de difícil manuseio ${ }^{64}$.

O reforço de estruturas tubulares de silicone por telas de tecido, tornando-as mais moles e flexíveis, já foi descrito como forma de adequar estes tubos para implantes e suturas ${ }^{25,59,60}$

A hipótese de que próteses de PDMS possam ser utilizadas como substitutos de artérias de pequeno calibre representa o motivo da presente 
Introdução 10

pesquisa e, para tanto, foi realizada a comparação do uso dessas com as próteses de PTFE, já conhecidas e de uso frequente em revascularizações arteriais. 
2. OBJETIVOS 
Os objetivos da presente pesquisa, em modelo experimental em coelhos, são:

- Comparar a patência das próteses de PDMS e PTFE através de arteriografia por fluoroscopia;

- Comparar características do implante cirúrgico dessas próteses;

- Comparar as complicações pós-operatórias do implante das próteses

- Avaliar e comparar o comportamento biológico das próteses. 
3. MÉTODOS 


\subsection{Animal de experimentação}

Os animais de experimentação utilizados na pesquisa foram coelhos domésticos (Oryctolagus cuniculus) adultos, da raça New Zealand, de ambos os sexos, com peso variando entre 3000 e 4900 gramas, provenientes do Centro de Bioterismo da Faculdade de Medicina da USP.

Os animais foram enviados ao Laboratório de Cirurgia Experimental da Faculdade de Medicina da USP, local onde foram realizados os procedimentos cirúrgicos.

Os animais foram submetidos a procedimentos cirúrgicos, sob anestesia, de acordo com a Diretriz do Conselho Nacional de Controle de Experimentação Animal - CONCEA ${ }^{65}$.

O estudo foi realizado com autorização do Comitê de Ética da Faculdade de Medicina da Universidade de São Paulo.

\subsection{Próteses}

Foram utilizadas próteses vasculares de dois tipos:

- Próteses de PDMS tubulares, retas, de parede fina $(0,4 \mathrm{~mm})$ e com diâmetro de $4 \mathrm{~mm}$.

- Próteses de PTFE tubulares, retas, de parede fina $(0,41 \mathrm{~mm})$ e sem reforço anelar externo, com diâmetro de $4 \mathrm{~mm}$. 
Para a confecção das próteses de PDMS, foi utilizado silicone liquido de grau médico, que foi curado sobre um mandril metálico onde era colocada tela de tecido de poliéster (Figura 2).O tecido foi colocado a fim de aumentar a tolerância ao rasgo do silicone durante a sutura para implante da prótese. O mandril era mantido em movimento rotatório, inicialmente em temperatura ambiente, a fim de que a cura ocorresse de maneira uniforme, e posteriormente era colocado em estufa à temperatura de $110^{\circ} \mathrm{C}$ por 30 minutos. Essas próteses foram confeccionadas segundo patente de número PI 074867-0 de De Luccia e De Luccia66 (Figuras 3 e 4).

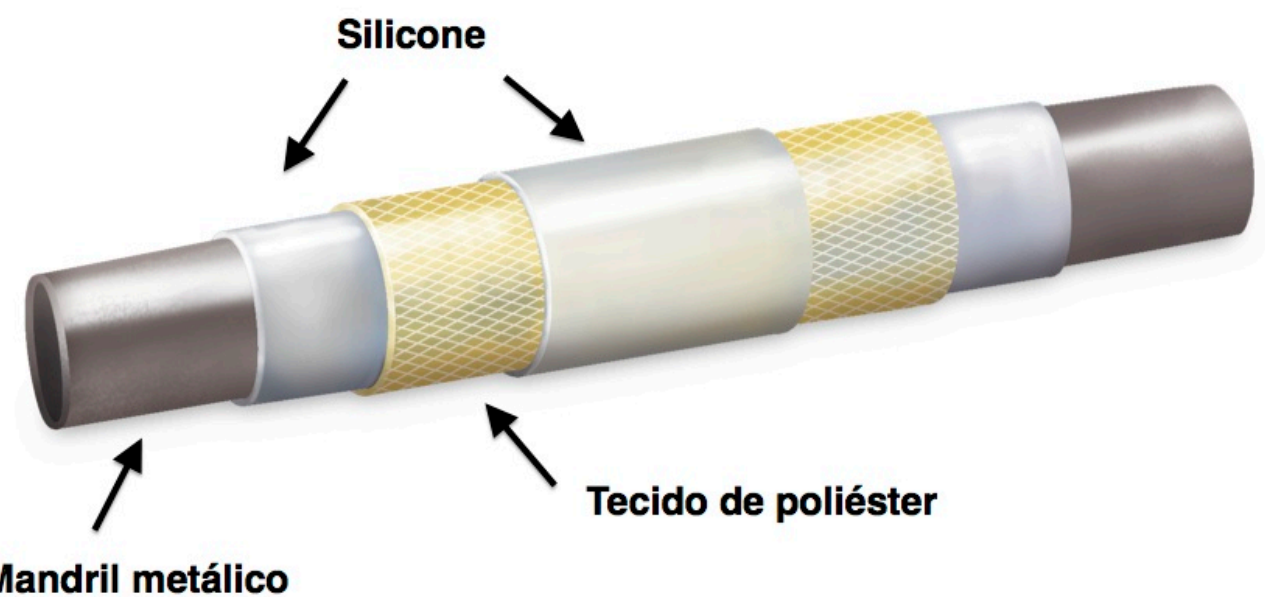

Figura 2 - llustração da prótese de PDMS. 


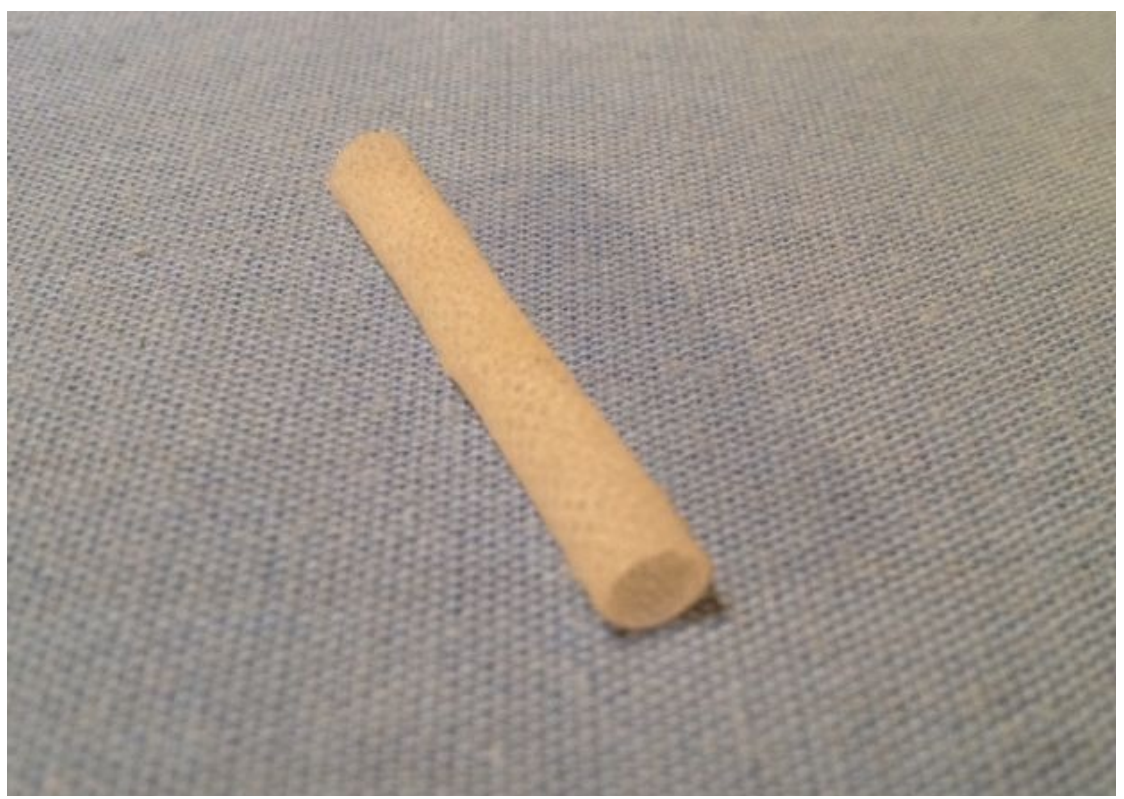

Figura 3 - Prótese de PDMS.

\subsection{Plano experimental}

Foram incluídos no estudo 40 animais.

Os animais foram divididos em dois grupos, de acordo com a prótese implantada:

- Grupo PDMS: coelhos submetidos ao implante de prótese de PDMS $(n=20)$.

- Grupo PTFE: coelhos submetidos ao implante de prótese de PTFE $(n=20)$. 


\subsubsection{Técnica anestésica}

Todos os procedimentos foram realizados sob anestesia geral e a técnica anestésica empregada consistiu em administração de Cloridrato de Quetamina $50 \mathrm{mg} / \mathrm{mL}$ (Ketamin®, Cristália) na dose de $35 \mathrm{mg} / \mathrm{kg}$ e Cloridrato de Xilazina $2 \%$ (Anasedan ${ }^{\circ}$, Vertbrands) na dose de $5 \mathrm{mg} / \mathrm{kg}$, ambos colocados em uma mesma seringa, e administrados por via intramuscular na coxa ou região glútea, como medicação pré-anestésica ${ }^{67}$.

Decorridos 10 minutos, a veia marginal da orelha foi puncionada com cateter vascular (Jelco) de calibre 22 ou 24 G. Uma vez estabelecido o acesso venoso, passava-se à anestesia endovenosa com as mesmas drogas utilizadas no pré-anestésico, administradas de acordo com a necessidade dos animais durante o procedimento cirúrgico. Os animais receberam, também por via endovenosa, hidratação com solução fisiológica (cloreto de sódio a $0,9 \%$ ) na dose de $15 \mathrm{~mL} / \mathrm{Kg} / \mathrm{hora}$ durante todo o procedimento.

A intubação orotraqueal em coelhos mostrou-se difícil e traumática aos animais desde a fase mais inicial da pesquisa, o que aumentou a morbidade e mortalidade dos animais nesse período. Devido a isso, os animais foram mantidos sob ventilação espontânea, com cateter de oxigênio a $3 \mathrm{~L} / \mathrm{min}$ 


\subsubsection{Técnica cirúrgica}

Com o animal sob anestesia geral, foi realizada laparotomia mediana para acesso à aorta abdominal por via transperitoneal. Após a laparotomia, era colocado afastador autoestático desenvolvido para a pesquisa, a fim de manter e facilitar a exposição do campo operatório (Figura 4).

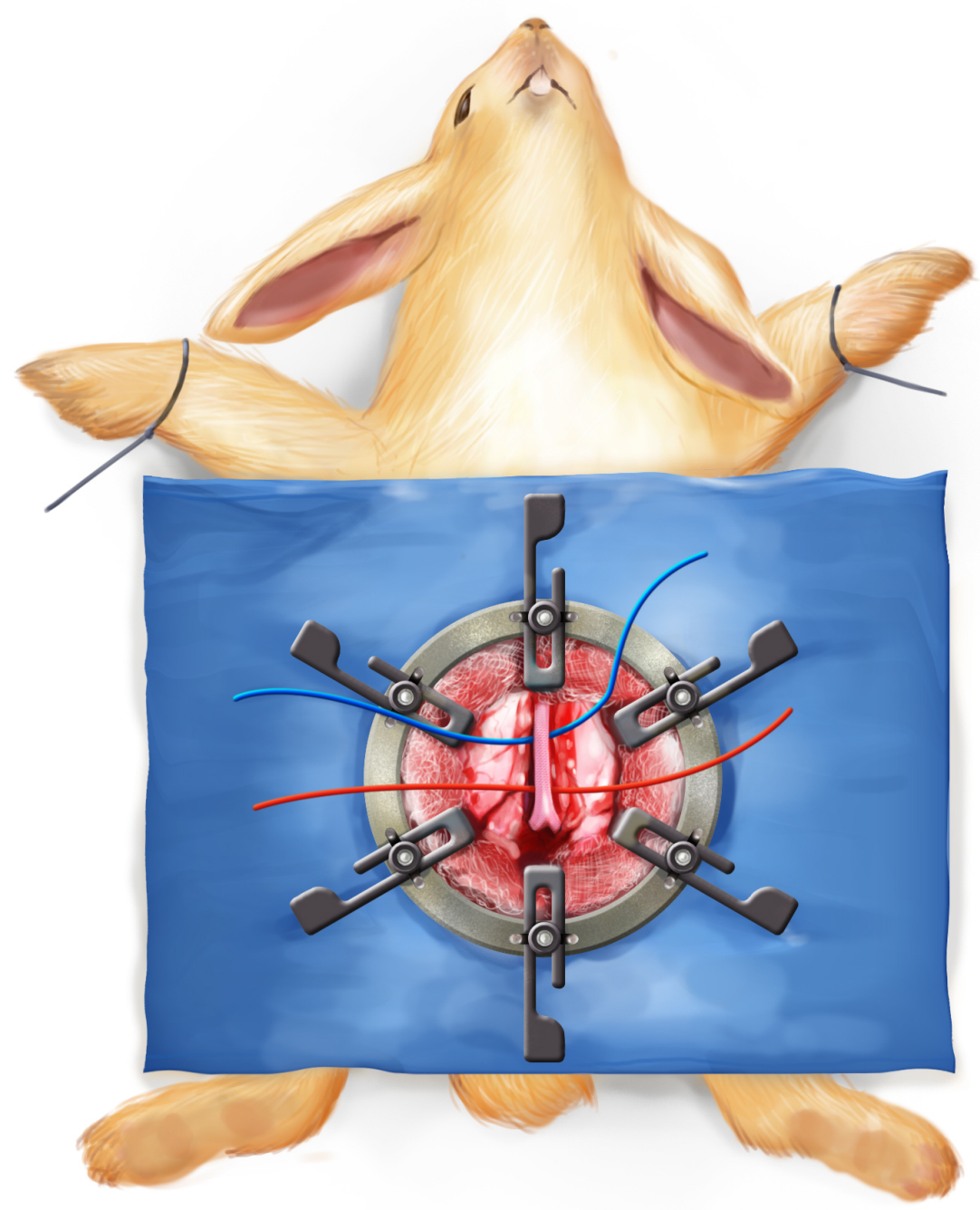

Figura 4 - Ilustração do animal com aorta abdominal dissecada e reparada. 
Após a dissecção de um segmento de aproximadamente $4 \mathrm{~cm}$ da aorta infrarrenal e reparo proximal e distal da mesma, o animal foi anticoagulado. A anticoagulação foi feita com heparina sódica $5000 \mathrm{Ul} / \mathrm{mL}$ (Liquemine ${ }^{\circledR}$, Roche), na dose de 200 Ul/kg, por via endovenosa. Decorridos 2 minutos da administração da heparina, os seguimentos proximal e distal da aorta foram clampeados, assim como eventuais artérias lombares encontradas. Sempre que possível, a ligadura e secção das artérias lombares foi evitada a fim de reduzir a ocorrência de paraplegia no período pós-operatório (Figura 5).

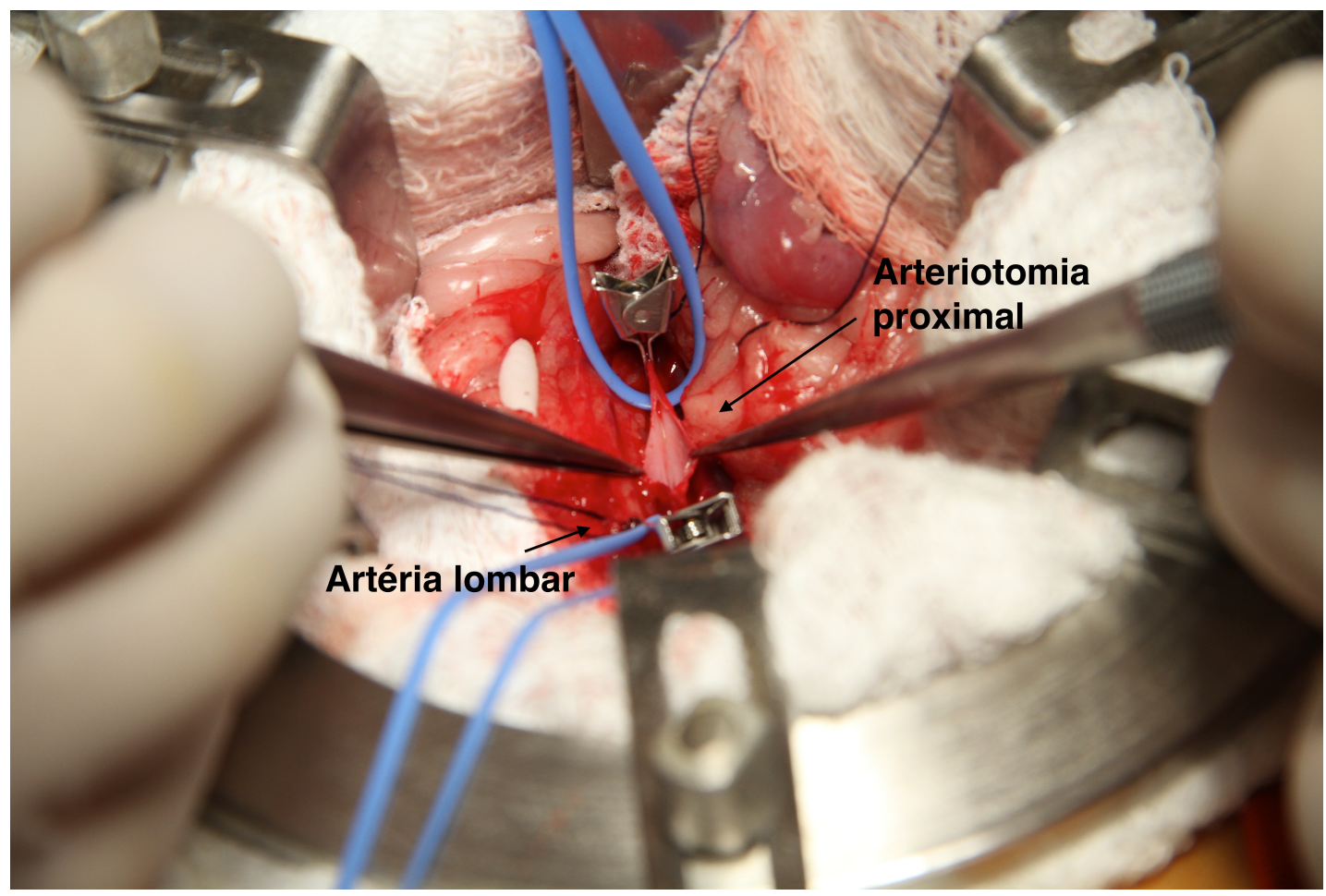

Figura 5 - Aorta dissecada, clampeada e aberta (arteriotomia proximal). 
Procedia-se então à realização das anastomoses da prótese selecionada (PTFE ou PDMS) na aorta do animal, por técnica términolateral, com suturas contínuas com fio de polipropileno 7-0, com agulha cardiovascular $3 / 8-1 \mathrm{~cm}$ (Prolene ${ }^{\circledR}$, Ethicon). A anastomose proximal foi a primeira a ser realizada e, após a conclusão da mesma, os clamps eram liberados por alguns minutos com a finalidade de restaurar a perfusão dos membros inferiores e realizar a proteção tecidual através de précondicionamento isquêmico. Seguia-se então à recolocação dos clamps e à confecção da anastomose distal.

Finalizadas as anastomoses, os clamps eram removidos e realizavase a ligadura da aorta entre as anastomoses em dois níveis, com fio de algodão 4-0, seguida da secção do vaso entre as duas ligaduras (Figuras 6 e 7)

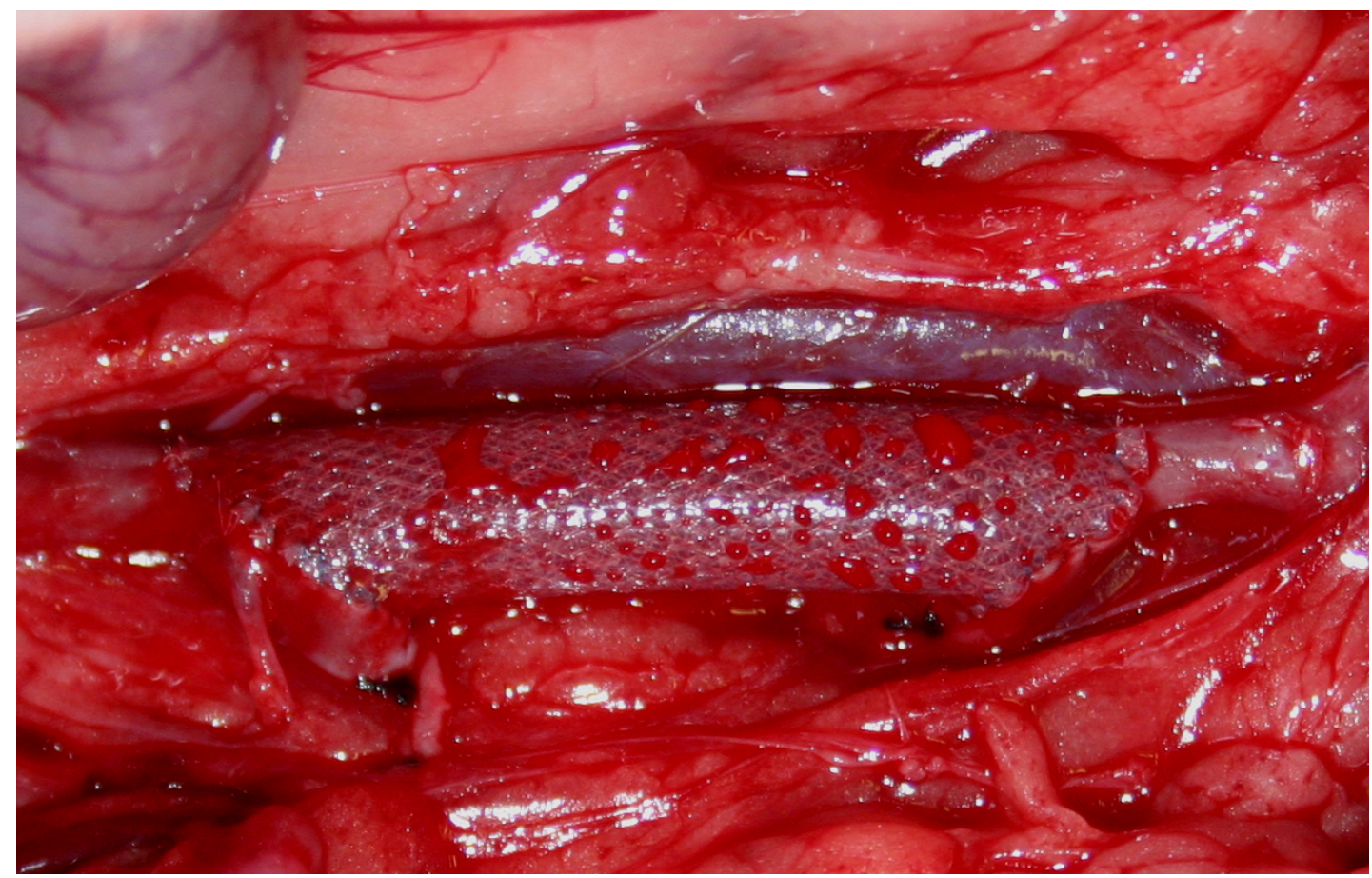

Figura 6 - Prótese de PDMS implantada. 


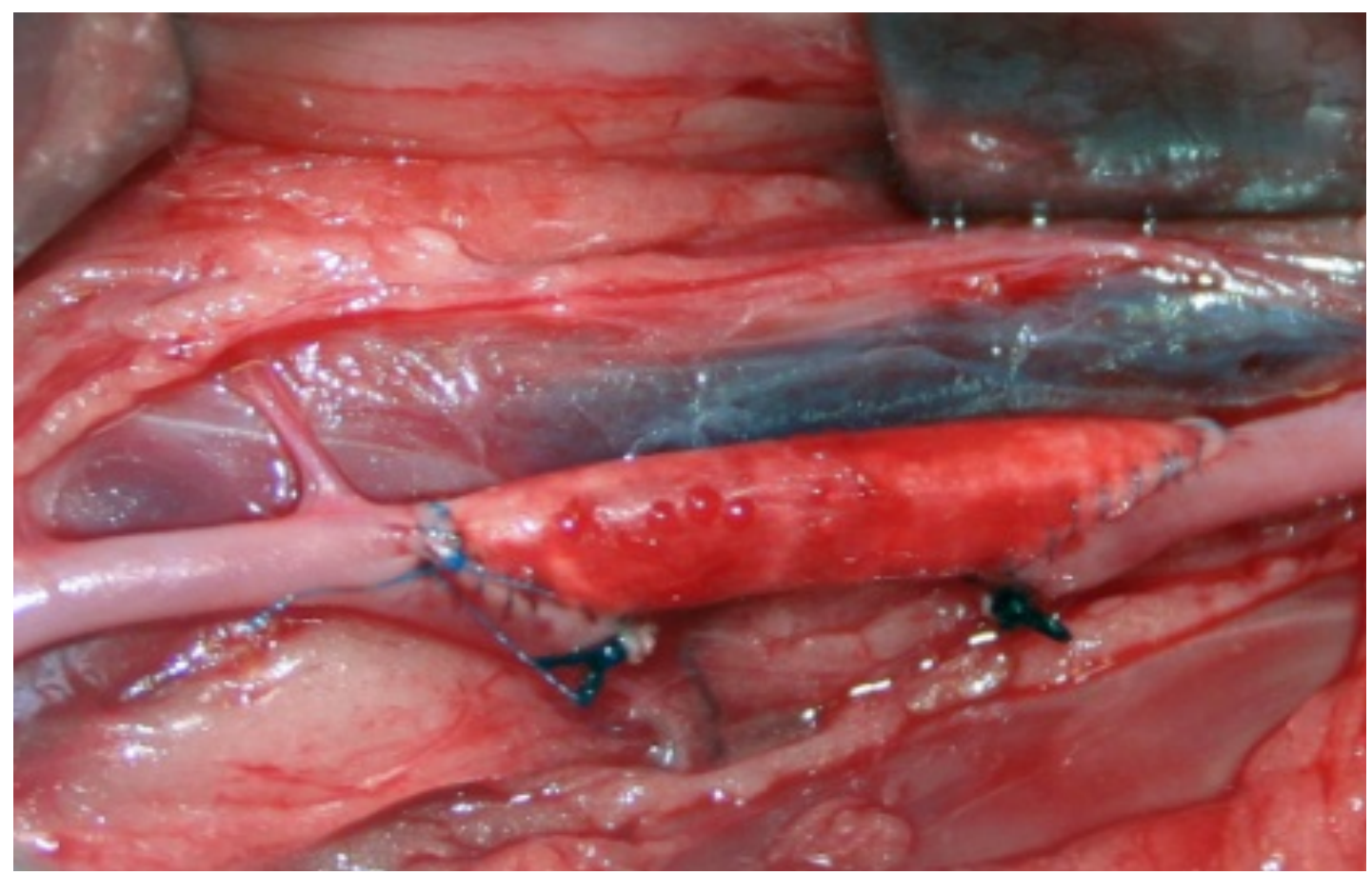

Figura 7 - Prótese de PTFE implantada.

O fechamento do plano muscular foi realizado com sutura contínua simples com fio poliglactina 3-0; e a pele com sutura contínua simples com nylon 4-0.

O tempo principal do procedimento encontra-se representado na figura 8. 

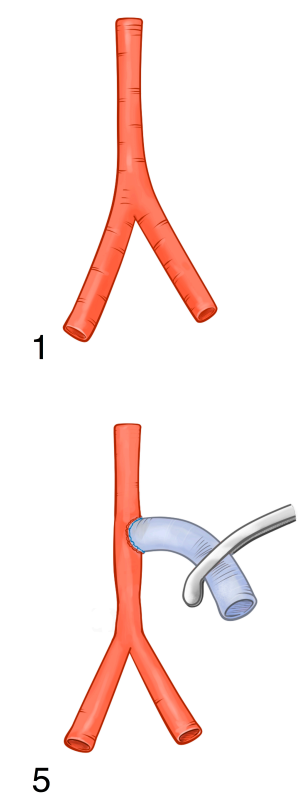
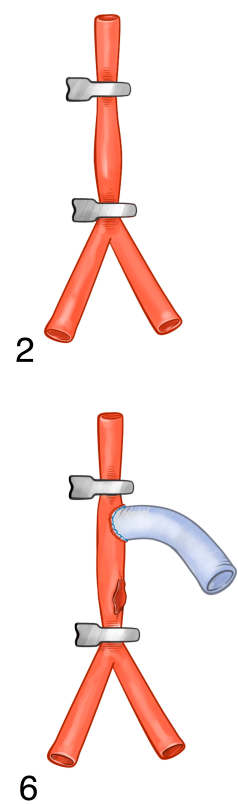
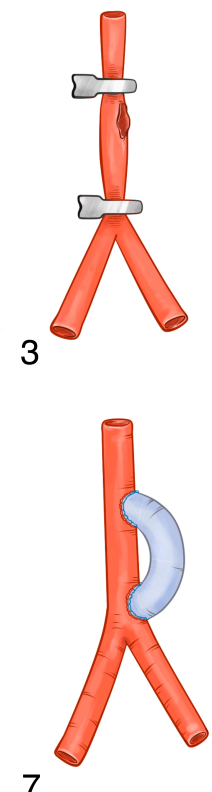
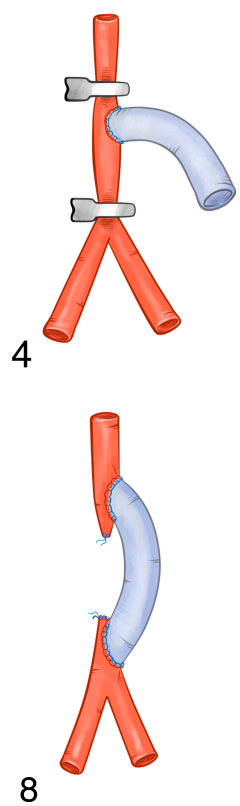

ADAPTADO de: Ribas, LM $2013^{68}$

Figura 8 - Tempo principal do implante cirúrgico das próteses: 1-Aorta infrarrenal dissecada; 2-Aorta clampeada; 3-Arteriotomia proximal; 4Anastomose proximal; 5 - Retirada dos clamps da aorta e précondicionamento isquêmico; 6 - Arteriotomia distal; 7 - Prótese implantada; 8-Aorta ligada e seccionada.

O tempo de clampeamento da aorta foi medido somando-se os tempos do primeiro e segundo clampeamentos, sendo desconsiderado o tempo de pré-condicionamento isquêmico.

Ao término do procedimento, os animais receberam analgesia pósoperatória com Meloxican a $2 \%$ (Maxicam ${ }^{\circledR}$, Ouro Fino), na dose de $0,2 \mathrm{mg} / \mathrm{kg}$, por via intramuscular. 


\subsubsection{Período pós-operatório}

Após a realização dos procedimentos cirúrgicos, os animais que apresentaram boa evolução clínica foram mantidos em biotério por, no mínimo, 4 semanas em gaiolas apropriadas, com água e ração ad libitum,

Os animais que apresentaram paraplegia foram submetidos a eutanásia com cloreto de potássio a 19,1\% por via endovenosa, após serem anestesiados (mesma técnica usada nos procedimentos cirúrgicos).

\subsection{Avaliação das próteses}

Decorrido período mínimo de 28 dias, os animais foram novamente anestesiados (metodologia descrita anteriormente) e submetidos a arteriografia retrógrada por fluoroscopia, através da injeção de contraste iodado (Reliev 60\%) por cateter de Silastic® introduzido pela artéria femoral, após dissecção da mesma (Figura 9). Através da aortografia, determinou-se a patência e o grau de estenose das próteses (Figura 10). Os exames foram realizados com equipamento OEC Diasonics®. 

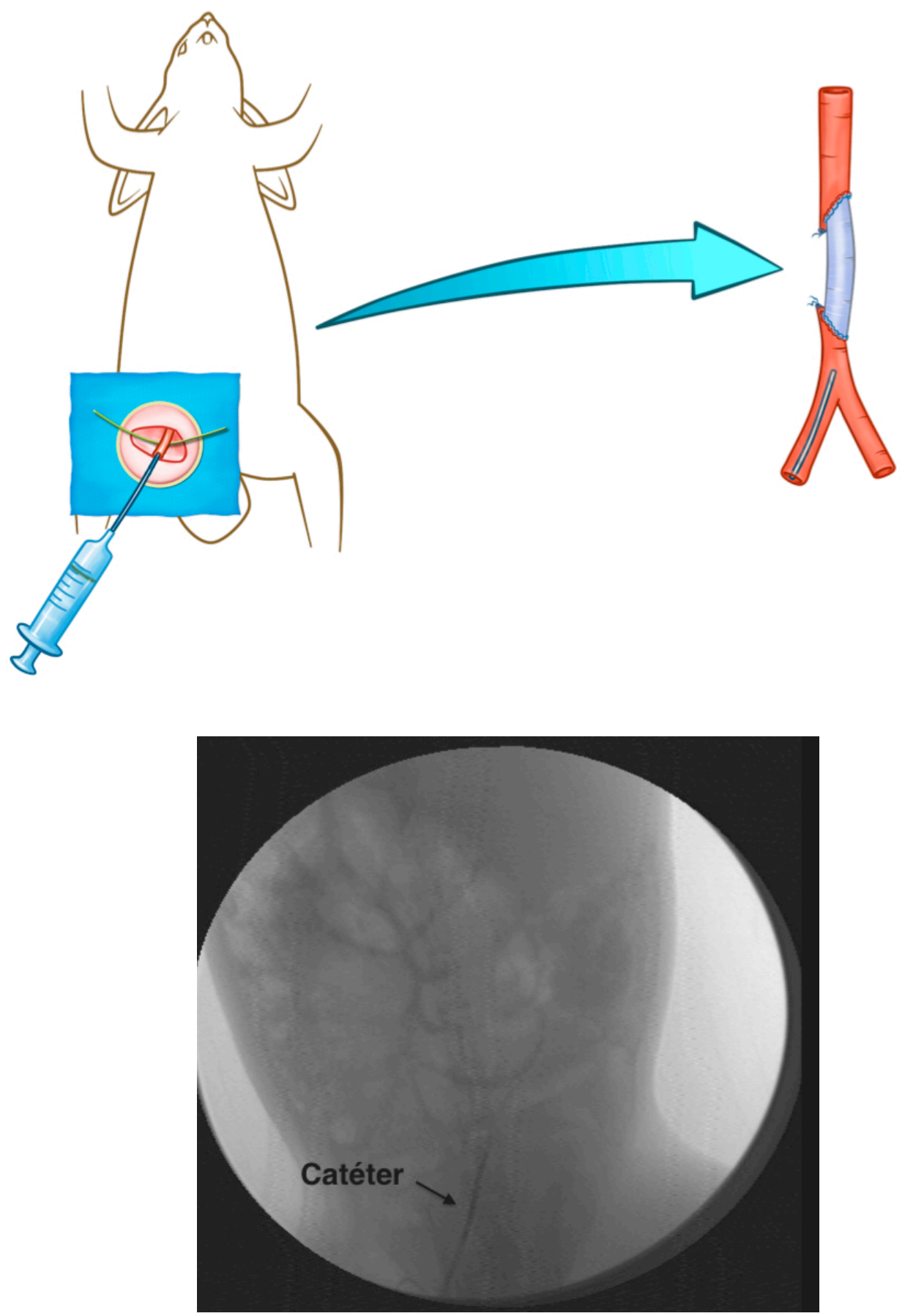

Figura 9 - Artéria femoral dissecada e cateterizada para realização da arteriografia, cateter visualizado à fluoroscopia. 


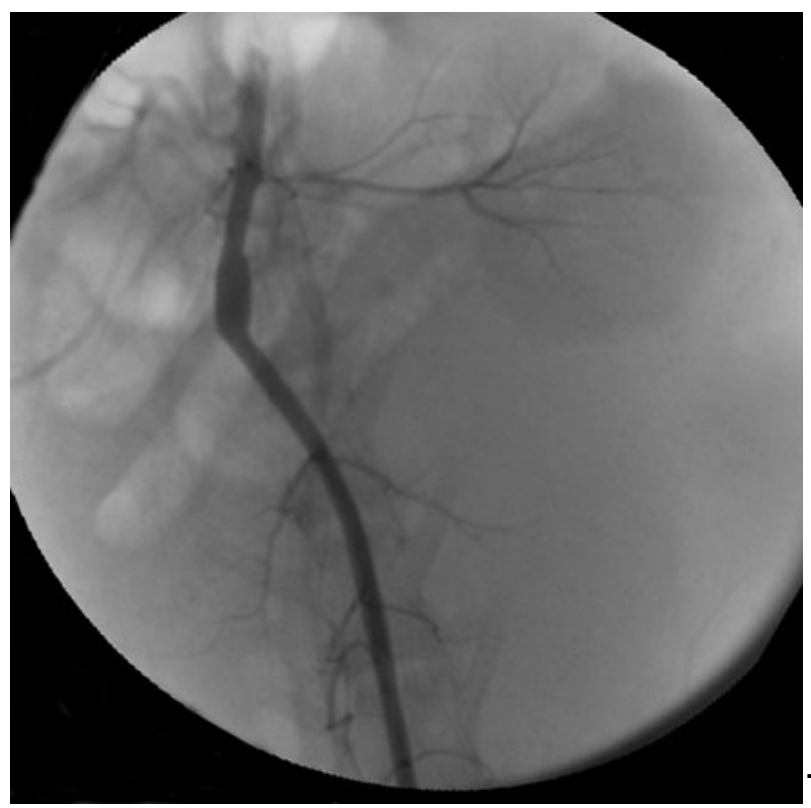

Figura 10 - Angiografia da aorta de coelho na qual foi implantado enxerto de PDMS - $30^{\circ}$ dia pós-operatório.

As próteses foram classificadas em patentes ou ocluídas, de acordo com a passagem ou não de contraste pelas mesmas. As próteses patentes foram avaliadas quanto ao grau de estenose através de software disponível no equipamento. A porcentagem do grau de estenose foi calculada através da relação entre a medida do menor diâmetro da luz da prótese em relação ao diâmetro da luz dos segmentos proximal e distal da aorta. Após a conclusão do exame angiográfico os animais, ainda anestesiados, foram submetidos a eutanásia com cloreto de potássio a 19,1\%.

Após a eutanásia, foi realizada a dissecção da região operada, com inspeção macroscópica do implante e remoção da peça (implante sintético e segmentos arteriais proximal e distal). 
Os corpos dos animais foram destinados de acordo com a rotina da Disciplina de Técnica Cirúrgica.

A microscopia ótica não foi passível de realização devido às características do material, que era explantado pelo micrótomo na tentativa de preparo das lâminas.

Foi realizada microscopia eletrônica de varredura, de maneira amostral nos enxertos patentes, a fim de se observar a superfície interna da prótese e a endotelização da mesma. A microscopia eletrônica foi realizada na Escola Politécnica da Universidade de São Paulo, no Departamento de Engenharia de Minas, em equipamento XL30 - Philips ${ }^{\circledR}$.

\subsection{Análise estatística}

Com as informações obtidas com os experimentos foi criado um banco de dados no programa Excel for Windows, o qual foi posteriormente utilizado para a análise estatística.

A análise estatística foi realizada através do programa SPSS ${ }^{\text {, }}$ versão 18.0.

A análise da associação das complicações (óbito e paraplegia) e a prótese utilizada foi feita através do teste exato de Fisher e teste quiquadrado. Os dados foram expressos através de gráficos em colunas. 
A análise da associação do tempo de clampeamento da aorta e o tipo de prótese implantada foi realizada através do teste $t$ de Student. Para a associação do tempo de clampeamento e as complicações em cada grupo foi utilizada a Análise de Variância a dois fatores (ANOVA a dois fatores), assim como para a análise da associação do tempo de clampeamento e a patência das próteses.

Para a análise da patência das próteses (medida em dias) foi utilizado o estimador não-paramétrico de Kaplan-Meier e, para comparar as curvas de patência, foi utilizado o teste de logrank. Foi considerado como evento a oclusão da prótese identificada no cateterismo. Os animais que apresentavam prótese patente no momento da aortografia, e que foram submetidos a eutanásia, após a realização do exame foram censurados na data do exame.

A hipótese de igualdade das médias foi rejeitada para $p<0,05(5 \%)$. 
4. RESULTADOS 
Foram operados 40 animais, com peso médio de $3,83 \mathrm{Kg}$ (com desvio padrão de $0,48 \mathrm{Kg}$ ), sendo 20 de cada grupo.

\subsection{Evolução clínica e complicações pós-operatórias}

A evolução clínica pós-operatória dos animais está apresentada na tabela 1 e gráfico 1. Foram consideradas complicações pós-operatórias: paraplegia, paraplegia seguida de óbito e óbito. Nenhum animal evoluiu com quadro de infecção pós-operatória.

Tabela 1 - Evolução pós-operatória dos animais por grupo

\begin{tabular}{lccccc}
\hline Grupo & $\begin{array}{c}\text { Sem } \\
\text { complicações }\end{array}$ & Paraplegia & $\begin{array}{c}\text { Paraplegia } \\
+ \text { óbito }\end{array}$ & Óbito & Total \\
\hline PDMS & $14(70,0 \%)$ & $3(15,0 \%)$ & $2(10,0 \%)$ & $1(5,0 \%)$ & $20(100,0 \%)$ \\
PTFE & $11(55,0 \%)$ & $4(20,0 \%)$ & $1(5,0 \%)$ & $4(20,0 \%)$ & $20(100,0 \%)$ \\
\hline Total & $25(62,5 \%)$ & $7(17,5 \%)$ & $3(7,5 \%)$ & $5(12,5 \%)$ & $40(100,0 \%)$ \\
\hline
\end{tabular}


Gráfico 1 - Evolução pós-operatória dos animais por grupo

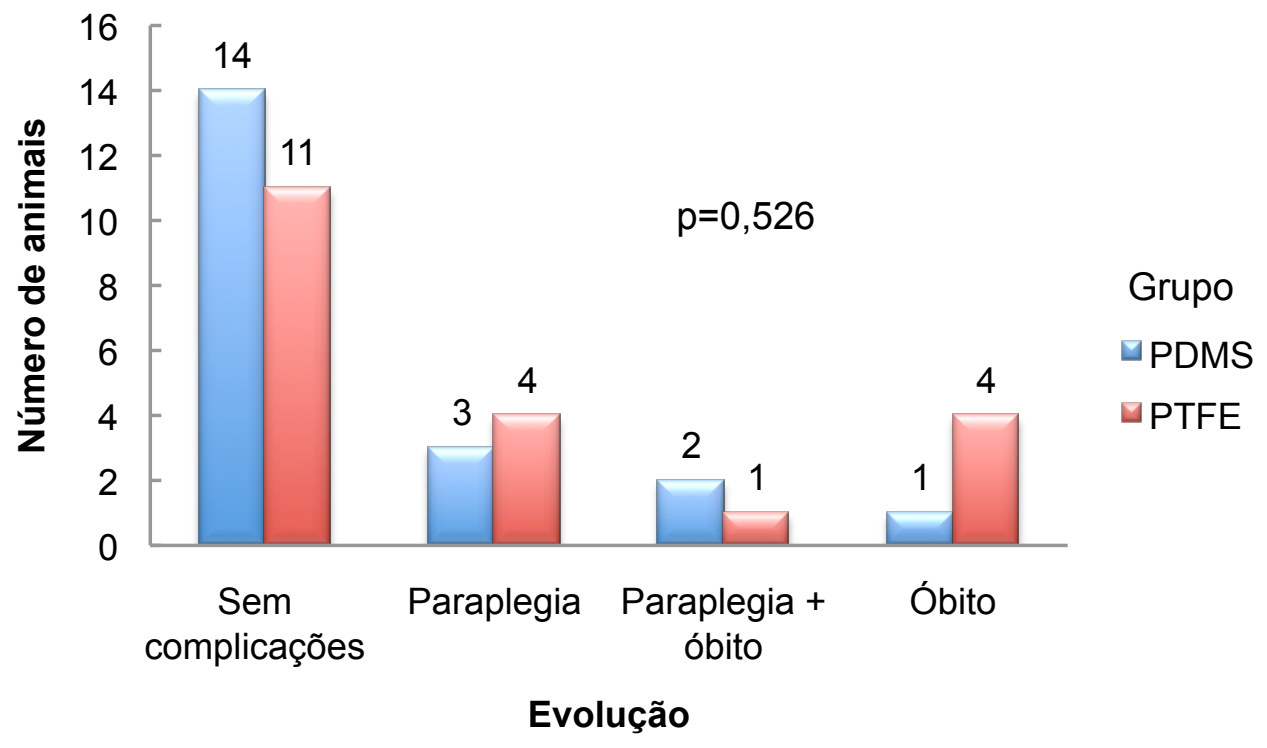

Não foi observada diferença entre os grupos quanto à evolução com complicações pós-operatórias (teste exato de Fisher, $p=0,526$ ).

O tempo médio de sobrevida dos animais que morreram foi de 2 dias e dos animais com paraplegia foi de 2,3 dias.

\subsubsection{Mortalidade}

Verificou-se que $3(3 / 20=15 \%)$ animais do Grupo PDMS e $5(5 / 20=$ 25\%) animais do Grupo PTFE morreram após o experimento (gráfico 2). A comparação entre os grupos não mostrou diferença significativa em relação à mortalidade (teste exato de Fisher, $p=0,695$ ).

Houve um total de 8 óbitos de animais do estudo $(20 \%=8 / 40)$. 
Gráfico 2 - Relação entre mortalidade e prótese utilizada

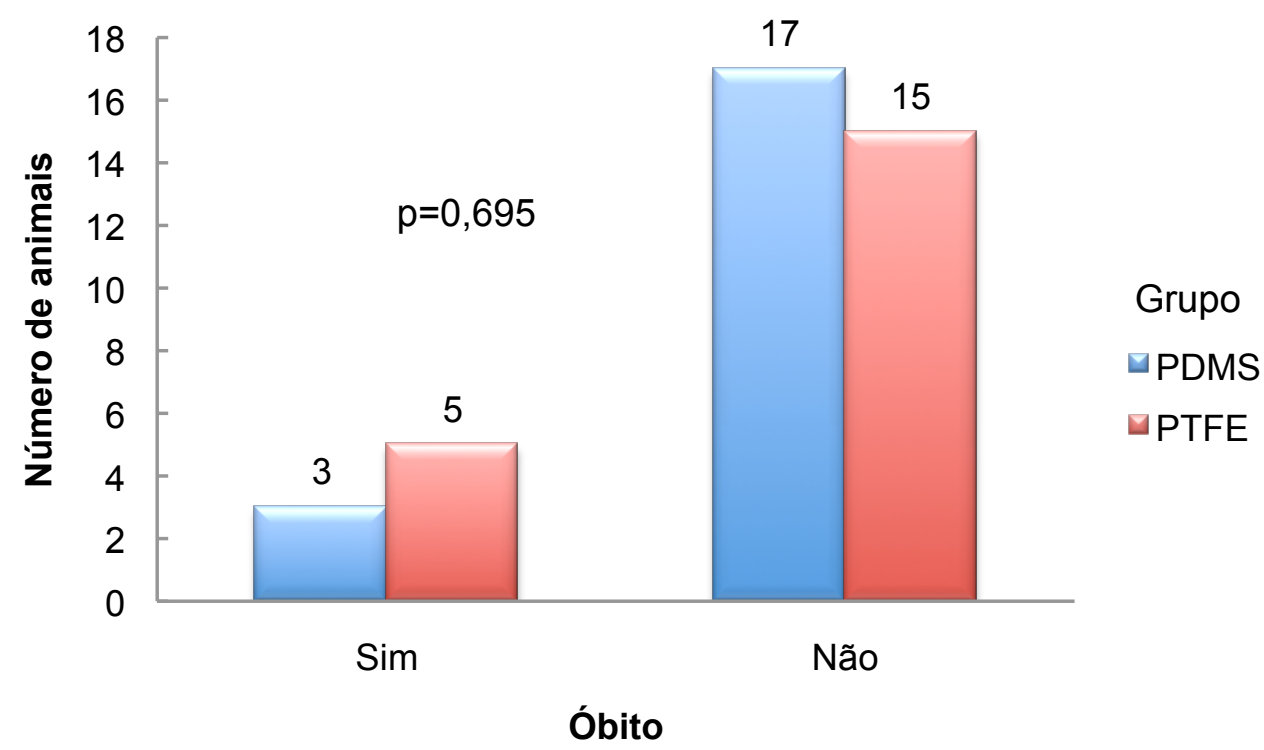

\subsubsection{Paraplegia}

No total, 10 animais ficaram paraplégicos após as operações; sendo 5 (25\%) animais de cada grupo. Não houve diferença significativa quanto à evolução para paraplegia (teste qui-quadrado $p=1,000$ ). 


\subsection{Tempo de clampeamento}

O tempo de clampeamento da aorta foi medido em minutos, com a intenção de se avaliar a facilidade na sutura e na confecção das anastomoses e, consequentemente, no implante da nova prótese em PDMS em comparação ao PTFE.

Tabela 2 - Tempo de clampeamento (em minutos)

\begin{tabular}{ccccc}
\hline Grupo & Média & Desvio padrão & Tempo mínimo & Tempo máximo \\
\hline PDMS & 50,70 & 11,86 & 37 & 80 \\
PTFE & 55,26 & 15,09 & 38 & 99 \\
\hline TOTAL & 52,92 & 13,55 & 37 & 99 \\
\hline
\end{tabular}

A análise dos tempos de clampeamento demonstrou que não houve diferença significativa entre os grupos (teste t de Student, $p=0,299$ ). 


\subsubsection{Tempo de clampeamento e complicações}

Tabela 3 - Tempo de clampeamento e complicações

\begin{tabular}{ccc}
\hline \multirow{2}{*}{ Grupo } & \multicolumn{2}{c}{ Tempo de clampeamento } \\
\cline { 2 - 3 } & \multicolumn{2}{c}{ Complicações } \\
\cline { 2 - 3 } & \multicolumn{2}{c}{ Não } \\
\hline PDMS & $47,83 \pm 9,75$ & $51,93 \pm 12,79$ \\
PTFE & $54,63 \pm 15,49$ & $55,73 \pm 15,54$ \\
\hline TOTAL & $51,71 \pm 13,34$ & $53,60 \pm 13,89$ \\
\hline
\end{tabular}

Observamos que não há diferença significativa entre os grupos quanto ao tempo de clampeamento da aorta, tanto no grupo que evoluiu com complicações como no grupo sem complicações (ANOVA a dois fatores: $p=0,264)$. Não observamos diferença significativa no tempo de clampeamento entre os animais que evoluíram com complicações e sem complicações, tanto no grupo PDMS como no grupo PTFE (ANOVA a dois fatores: $p=0,581$. 
Gráfico 3 - Tempo de clampeamento e complicações, segundo o grupo de estudo

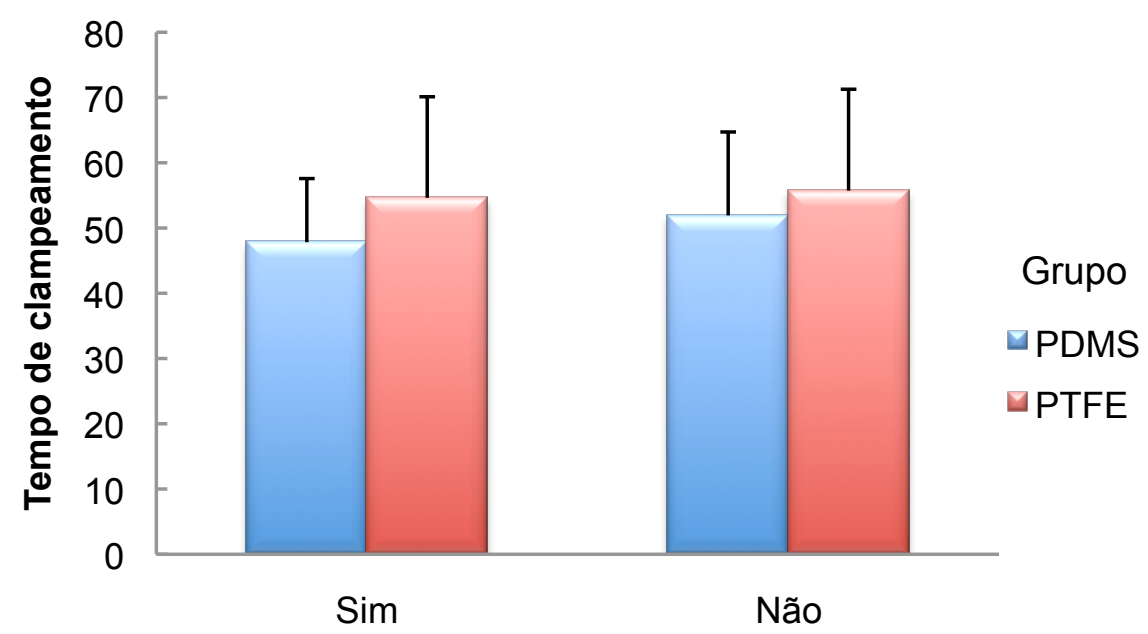

Complicação

\subsubsection{1 - Tempo de clampeamento e paraplegia}

Tabela 4 - Tempo de clampeamento e paraplegia

\begin{tabular}{ccc}
\hline & \multicolumn{2}{c}{ Tempo de clampeamento } \\
\cline { 2 - 3 } Grupo & \multicolumn{2}{c}{ Paraplegia } \\
\cline { 2 - 3 } & \multicolumn{2}{c}{ Sim } \\
\hline PDMS & $46,60 \pm 10,36$ & $52,07 \pm 12,34$ \\
PTFE & $48,60 \pm 7,50$ & $57,64 \pm 16,58$ \\
\hline TOTAL & $47,60 \pm 8,59$ & $54,76 \pm 14,55$ \\
\hline
\end{tabular}

Observamos que não há diferença significativa entre os grupos quanto ao tempo de clampeamento da aorta, tanto no grupo com paraplegia 
como no sem paraplegia (ANOVA a dois fatores: $p=0,449$ ). Não observamos diferença significativa no tempo de clampeamento entre os animais com e sem paraplegia, tanto no grupo PDMS como no grupo PTFE (ANOVA a dois fatores: $p=0,151)$.

Gráfico 4 - Tempo de clampeamento e paraplegia, segundo o grupo de estudo

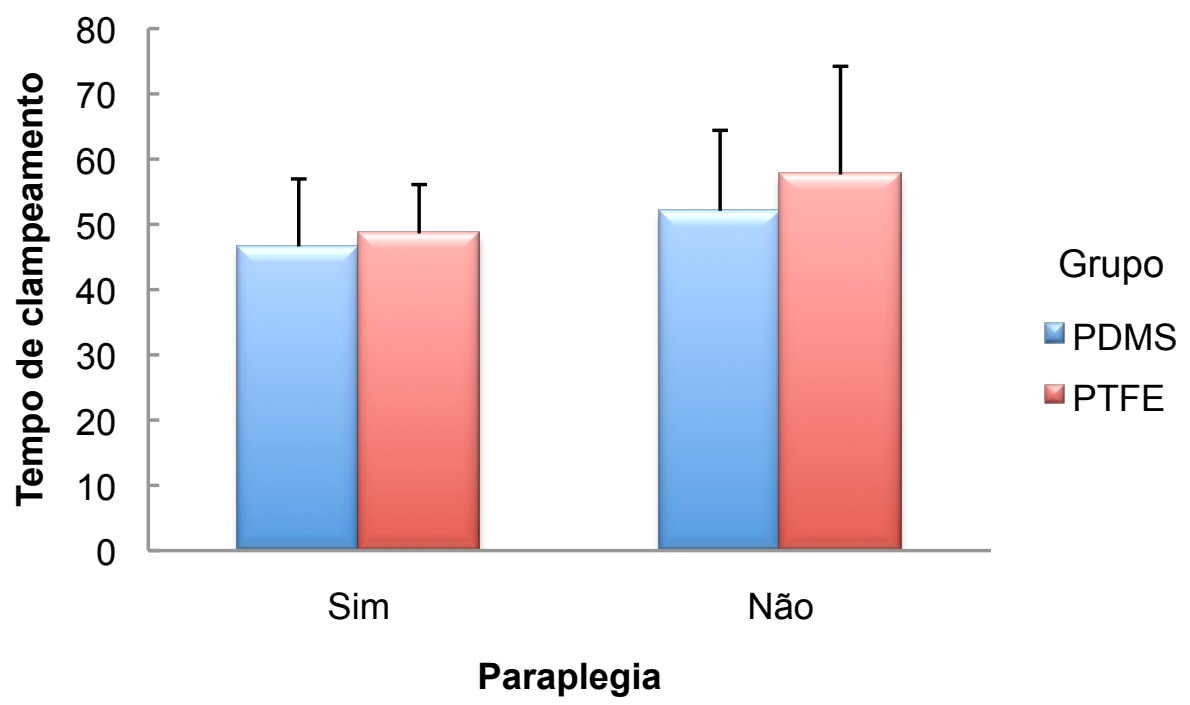




\subsubsection{2 - Tempo de clampeamento e óbitos}

Tabela 5 - Tempo de clampeamento e óbitos

\begin{tabular}{ccc}
\hline & \multicolumn{2}{c}{ Tempo de clampeamento } \\
\cline { 2 - 3 } Grupo & \multicolumn{2}{c}{ Óbito } \\
\cline { 2 - 3 } & \multicolumn{2}{c}{ Sim } \\
\hline PDMS & $46,33 \pm 6,81$ & $51,47 \pm 12,53$ \\
PTFE & $62,00 \pm 18,76$ & $53,47 \pm 14,18$ \\
\hline TOTAL & $55,29 \pm 16,17$ & $52,41 \pm 13,15$ \\
\hline
\end{tabular}

Observamos que não há diferença significativa entre os grupos quanto ao tempo de clampeamento da aorta, tanto no grupo que evoluiu a óbito como no grupo que sobreviveu (ANOVA a dois fatores: $p=0,132$ ). Não observamos diferença significativa no tempo de clampeamento entre os animais que morreram e aqueles que sobreviveram, tanto no grupo PDMS como no grupo PTFE (ANOVA a dois fatores: $p=0,769$ ). 
Gráfico 5 - Tempo de clampeamento e óbito, segundo o grupo de estudo

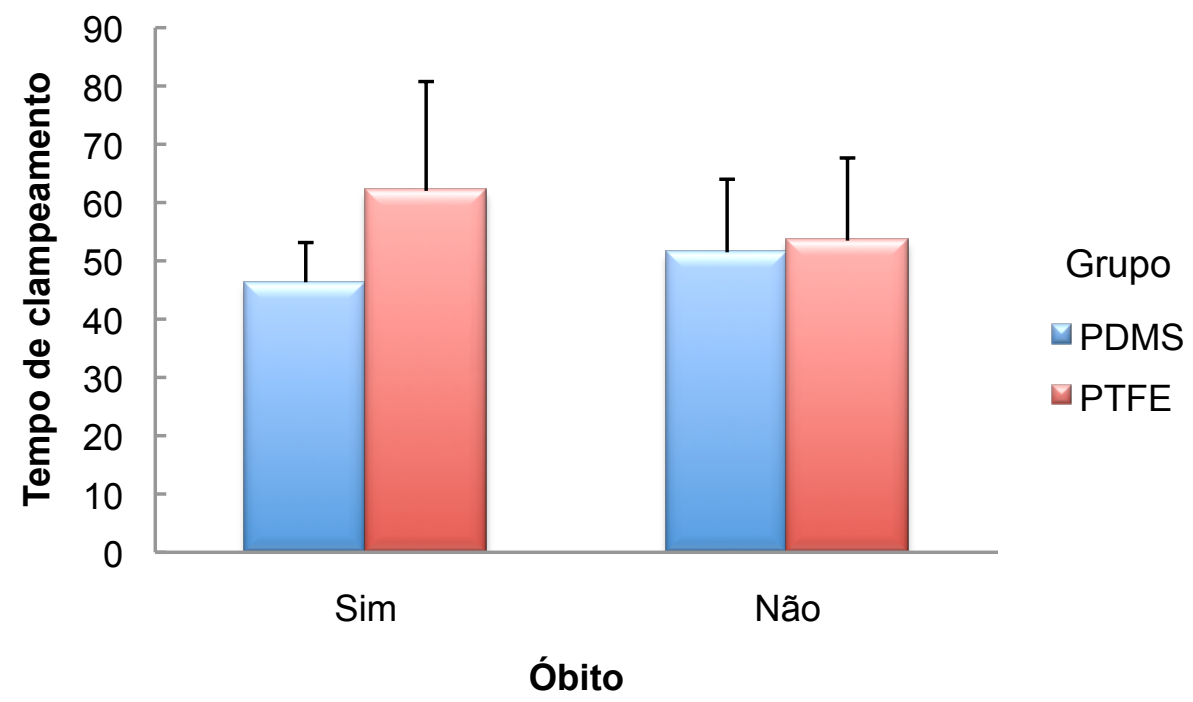

\subsubsection{Tempo de clampeamento e patência das próteses}

Tabela 6 - Tempo de clampeamento e patência das próteses

Tempo de clampeamento

Grupo

Prótese

Patente

Ocluída

\begin{tabular}{ccc}
\hline PDMS & $52,64 \pm 12,69$ & $49,33 \pm 13,11$ \\
PTFE & $53,17 \pm 15,84$ & $54,50 \pm 14,10$ \\
\hline TOTAL & $52,91 \pm 14,10$ & $51,40 \pm 10,39$ \\
\hline
\end{tabular}


Não observamos diferença significativa quanto ao tempo de clampeamento entre os grupos na condição patente ou ocluída (ANOVA a dois fatores: $p=0,587)$. Não observamos diferença significativa no tempo de clampeamento entre os animais que evoluíram com patência ou oclusão da prótese dentro de cada grupo (ANOVA a dois fatores: $p=0,851$ ).

Gráfico 6 - Tempo de clampeamento e patência, segundo o grupo de estudo

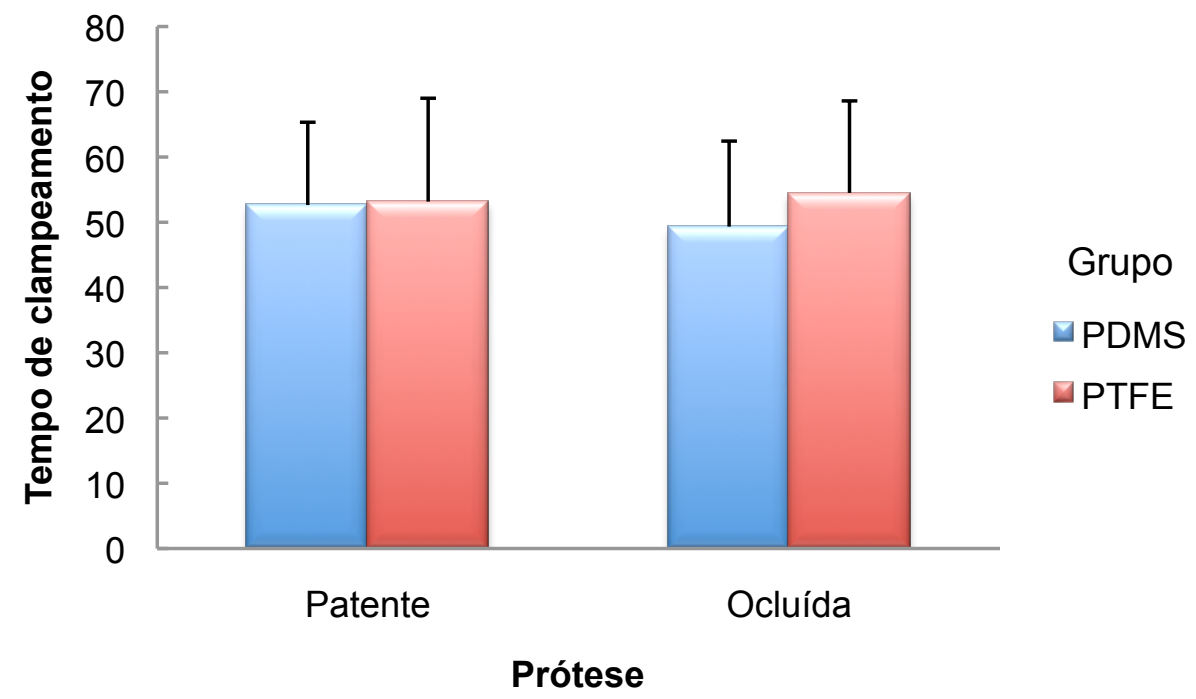

\subsection{Patência das próteses}

A patência das próteses foi medida em dias e avaliada a partir dos exames de aortografia (Figuras 11 a 13).

Foram realizadas 33 aortografias, 17 no grupo do PDMS e 16 no grupo do PTFE. Para a análise da patência das próteses foram excluídos oito animais (3 do grupo PDMS e 5 do grupo PTFE). Desse grupo de oito 
coelhos, cinco (2 do grupo PDMS e 3 do grupo PTFE) foram retirados da análise de patência por terem apresentado oclusão precoce (tempo menor que 28 dias), uma vez que essas oclusões geralmente estão relacionadas a falhas técnicas no procedimento cirúrgico e não apresentam relação com o tipo de próteses utilizadas ${ }^{69}$. Os outros 3 animais excluídos ( 2 do grupo PDMS e 1 do grupo PTFE) estavam com prótese patente mas haviam ficado parapégicos e a arteriogarfia foi realizada precocemente (até 2 dias após o implante das próteses), seguida da eutanásia dos animais.

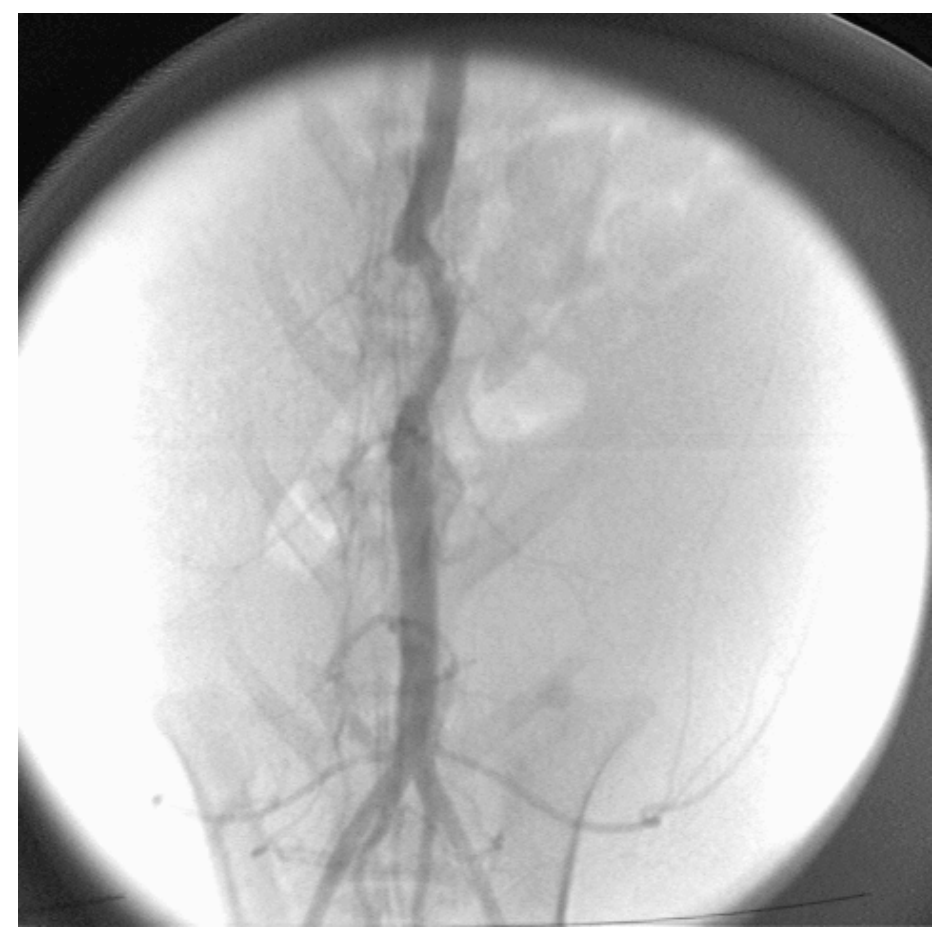

Figura 11 - Angiografia da aorta após 70 dias do implante de prótese de PTFE (prótese patente). 


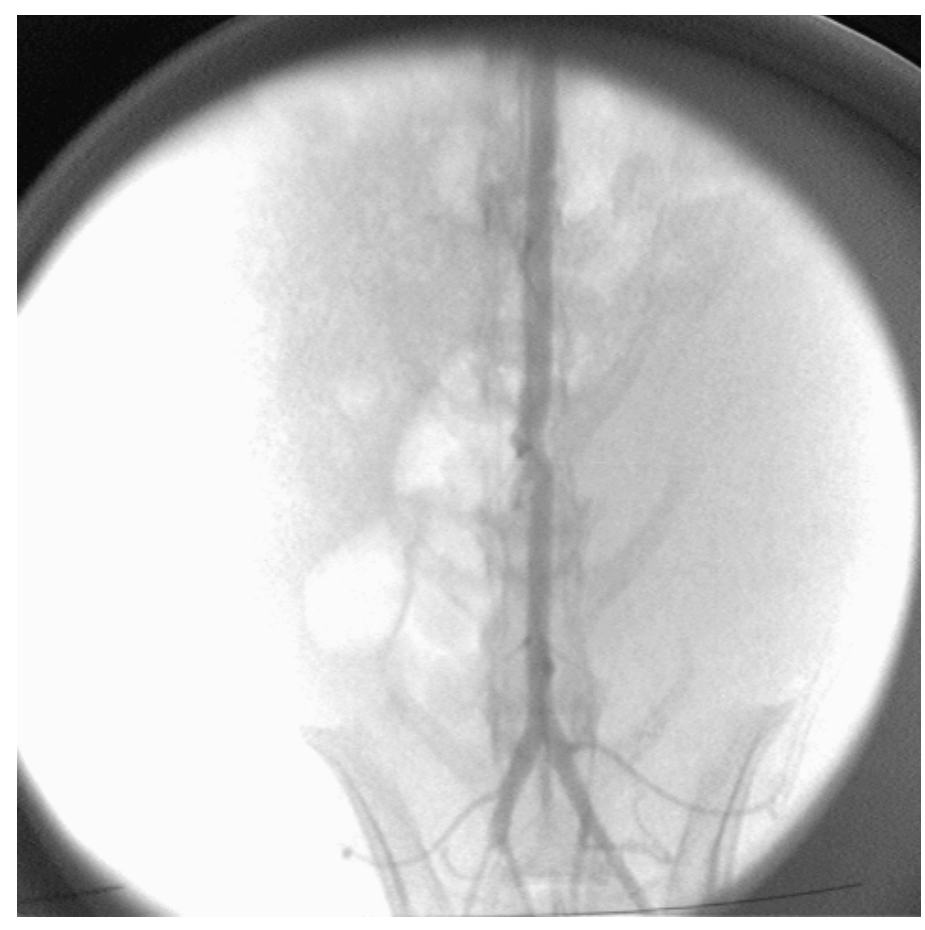

Figura 12 - Angiografia após 82 dias do implante de prótese de PDMS (prótese patente).

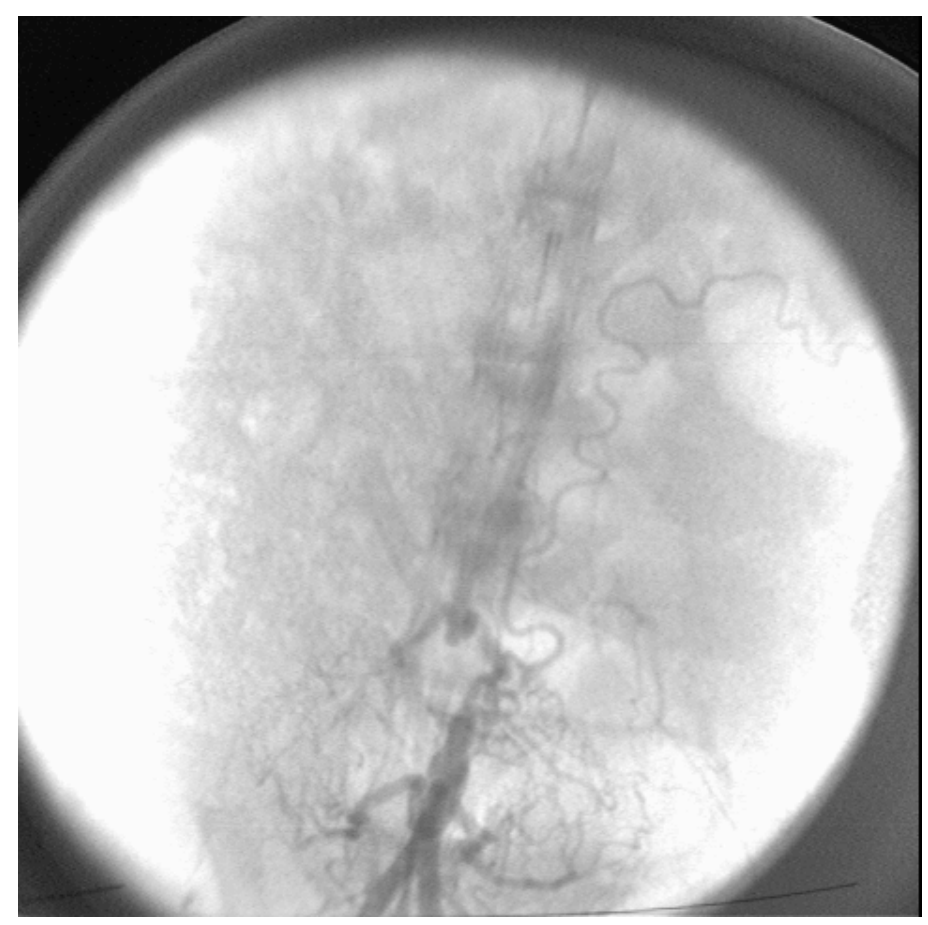

Figura 13 - Angiografia após 76 dias do implante de prótese de PDMS, com oclusão da mesma e circulação colateral exuberante. 
A patência das próteses foi analisada pelo método de Kaplan-Meier. No grupo PDMS, a patência em 30 dias foi de 100\%, em 60 dias foi de $92,3 \%( \pm 7,4)$ e em 90 dias de $73,8 \%( \pm 13,1)$. No grupo PTFE, a patência em 30 dias foi de $100 \%$, e em 60 e 90 dias foi de $87,5 \%( \pm 11,7)$. Através do teste de logrank, observa-se que não há diferença estatística significativa entre as taxas de patência dos grupos $(p=0,629)$ (Gráfico 7).

O risco de oclusão de cada grupo pode ser visto no gráfico 8.

Tabela 7 - Resumo dos dados da análise pelo método de Kaplan Meier

\begin{tabular}{ccccc}
\hline & & & & \multicolumn{2}{c}{ Censurados } \\
\cline { 4 - 5 } Grupo & total & $\begin{array}{c}\mathrm{N} \\
\text { Eventos } \\
\text { (oclusões) }\end{array}$ & $\begin{array}{c}\mathrm{N} \\
\text { (patente) }\end{array}$ & $\begin{array}{c}\text { Porcentagem } \\
(\%)\end{array}$ \\
\hline PDMS & 14 & 4 & 10 & $71,4 \%$ \\
PTFE & 11 & 1 & 10 & $90,9 \%$ \\
\hline TOTAL & 25 & 5 & 20 & $80 \%$ \\
\hline
\end{tabular}


Tabela 8 - Patência do grupo PDMS - Sobrevida na condição patente

\begin{tabular}{|c|c|c|c|c|c|c|}
\hline \multirow[b]{2}{*}{ Animal } & \multirow[b]{2}{*}{ Tempo } & \multirow[b]{2}{*}{ Status } & \multicolumn{2}{|c|}{$\begin{array}{l}\text { Proporção cumulativa } \\
\text { de patência }\end{array}$} & \multirow{2}{*}{$\begin{array}{l}\text { Número } \\
\text { cumulativo } \\
\text { de } \\
\text { oclusões }\end{array}$} & \multirow{2}{*}{$\begin{array}{l}\text { Número de } \\
\text { casos } \\
\text { remanescentes }\end{array}$} \\
\hline & & & Estimada & $\begin{array}{l}\text { Erro } \\
\text { Padrão }\end{array}$ & & \\
\hline 1 & 45 & patente & - & - & 0 & 13 \\
\hline 2 & 47 & ocluído & 0,923 & 0,074 & 1 & 12 \\
\hline 3 & 55 & patente & - & - & 1 & 11 \\
\hline 4 & 55 & patente & - & - & 1 & 10 \\
\hline 5 & 76 & ocluído & - & - & 2 & 9 \\
\hline 6 & 76 & ocluído & 0,738 & 0,131 & 3 & 8 \\
\hline 7 & 76 & patente & - & - & 3 & 7 \\
\hline 8 & 77 & patente & - & - & 3 & 6 \\
\hline 9 & 78 & patente & - & - & 3 & 5 \\
\hline 10 & 78 & patente & - & - & 3 & 4 \\
\hline 11 & 79 & patente & - & - & 3 & 3 \\
\hline 12 & 82 & patente & - & - & 3 & 2 \\
\hline 13 & 82 & patente & - & - & 3 & 1 \\
\hline 14 & 108 & ocluído & 0,00 & 0,00 & 4 & 0 \\
\hline
\end{tabular}


Tabela 9 - Patência do grupo PTFE - Sobrevida na condição patente

\begin{tabular}{cccccccc}
\hline \multirow{2}{*}{ Animal } & Tempo & Status & \multicolumn{2}{c}{$\begin{array}{c}\text { Proporção cumulativa } \\
\text { de patência }\end{array}$} & $\begin{array}{c}\text { Número } \\
\text { cumulativo } \\
\text { de eventos }\end{array}$ & $\begin{array}{c}\text { Número de } \\
\text { casos } \\
\text { remanescentes }\end{array}$ \\
\cline { 5 - 7 } 1 & 28 & patente & - & - & 0 & 10 \\
2 & 55 & patente & - & - & 0 & 9 \\
3 & 55 & patente & - & - & 0 & 8 \\
4 & 56 & ocluído & 0,875 & 0,117 & 1 & 7 \\
5 & 60 & patente & - & - & 1 & 6 \\
6 & 68 & patente & - & - & 1 & 5 \\
7 & 70 & patente & - & - & 1 & 4 \\
8 & 80 & patente & - & - & 1 & 3 \\
9 & 80 & patente & - & - & 1 & 2 \\
10 & 80 & patente & - & - & 1 & 1 \\
11 & 90 & patente & - & - & 1 & 0 \\
\hline
\end{tabular}


Gráfico 7 - Curvas de patência de Kaplan-Meier

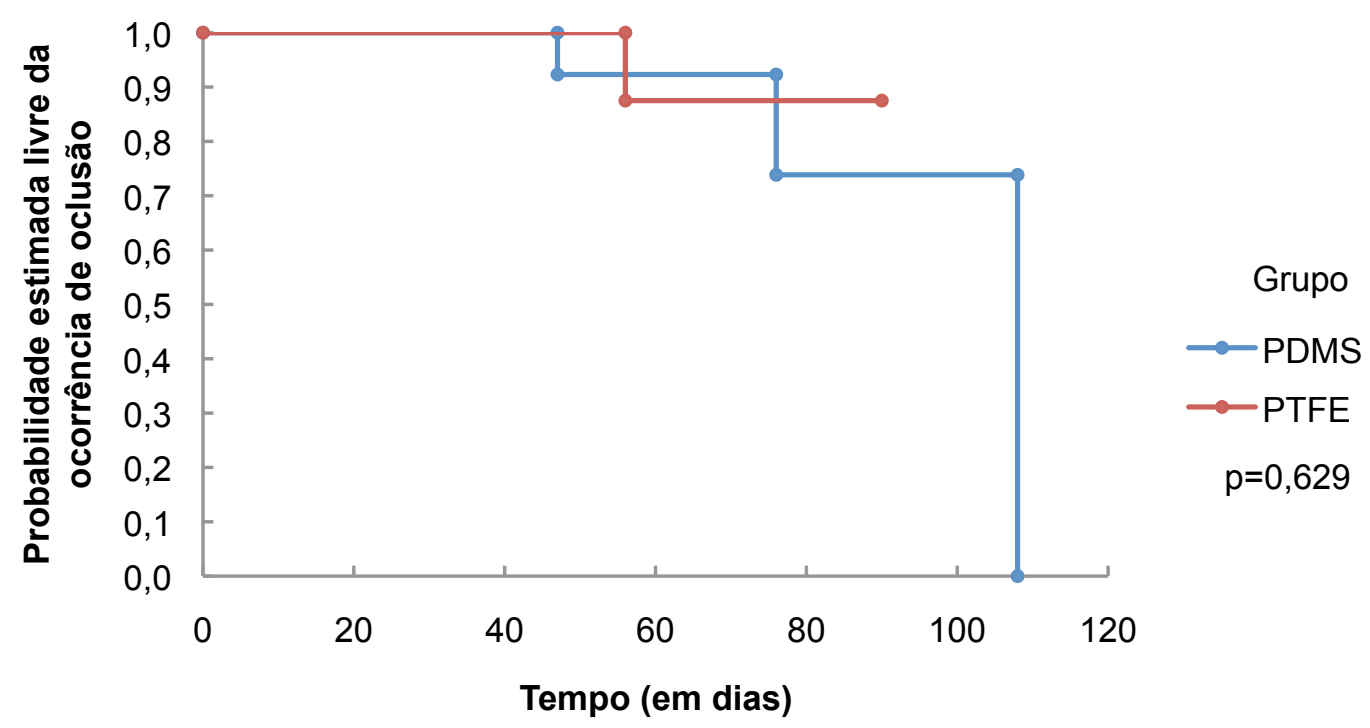

Gráfico 8 - Risco de oclusão estimado, segundo o grupo de estudo

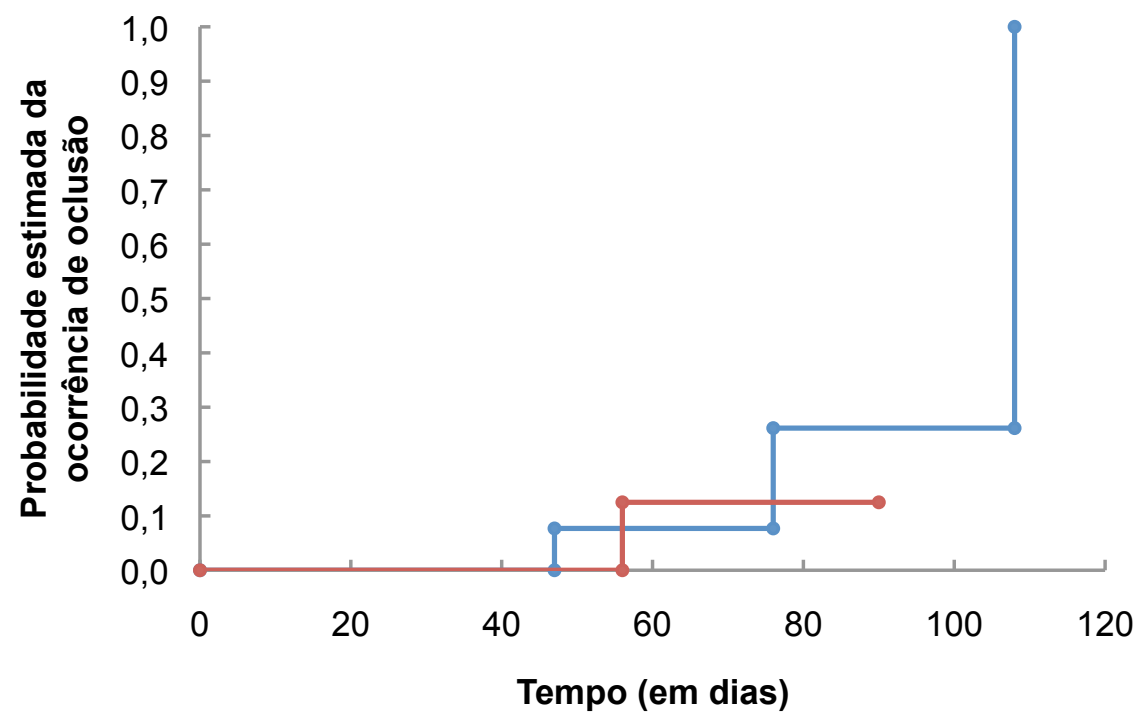

Grupo

$\because$ PDMS

$\because$ PTFE

$p=0,629$

20 


\subsection{Grau de estenose das próteses patentes}

A avaliação do grau de estenose das próteses patentes foi realizada a partir das arteriografias do mesmo grupo de animais que foram incluídos na análise da patência das próteses $(n=25)$.

No grupo dos animais com a prótese de PDMS, $10(10 / 14=71,4 \%)$ estavam com a prótese patente no momento do exame. Dentre os 10 animais, 5 (5/10) não apresentaram nenhum grau de estenose, 4 (4/10) estenoses entre 10 e $25 \%$ e $1(1 / 10)$ animal com estenose de $50 \%$. Nenhum animal nesse grupo apresentou estenose maior que 50\% (Figuras 14 a 16).

No grupo dos animais com a prótese de PTFE, $10(10 / 11=90,9 \%)$ apresentavam prótese patente no momento do exame. Dos animais com as próteses patentes, 7 (7/10) não apresentaram nenhum grau de estenose e 3 (3/10) apresentaram estenoses entre 10 e 25\%. Nenhum animal nesse grupo apresentou estenose maior que 25\% (Figuras 17 a 19).

Os grupos não apresentaram diferença significativa em relação ao grau de estenose das próteses (teste de Fisher, $p=0,650$ ). 


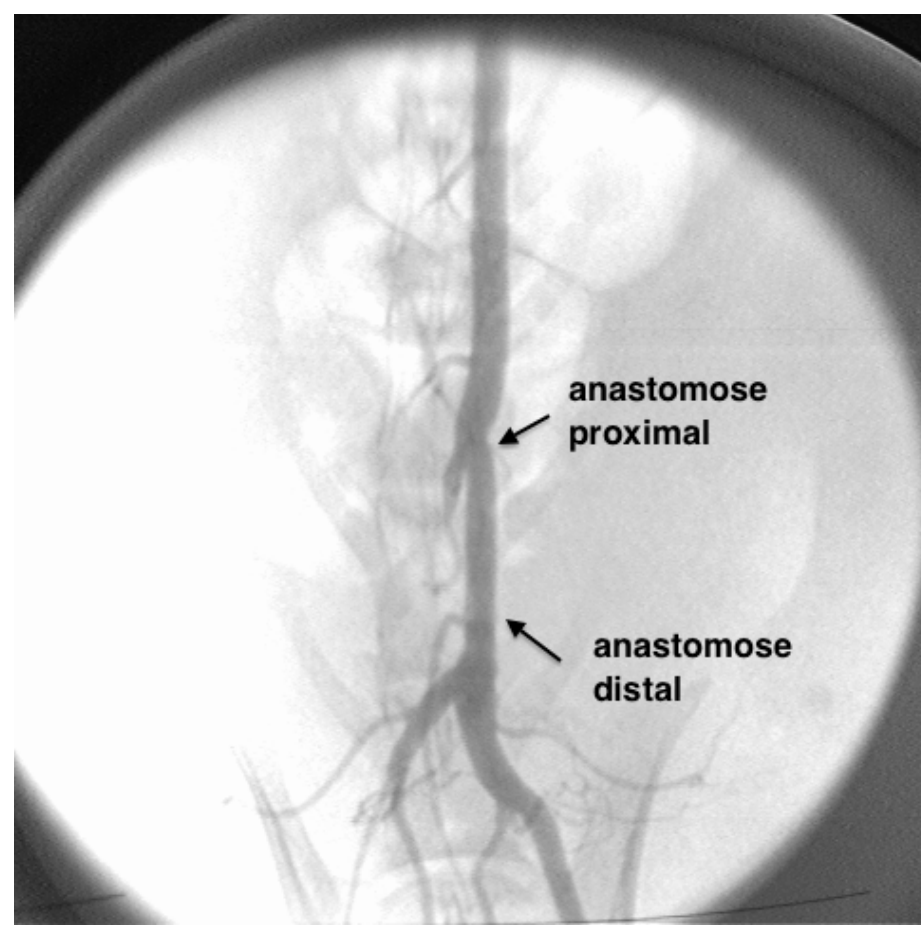

Figura 14 - Angiografia da aorta após 78 dias do implante de prótese de PDMS, sem estenoses.

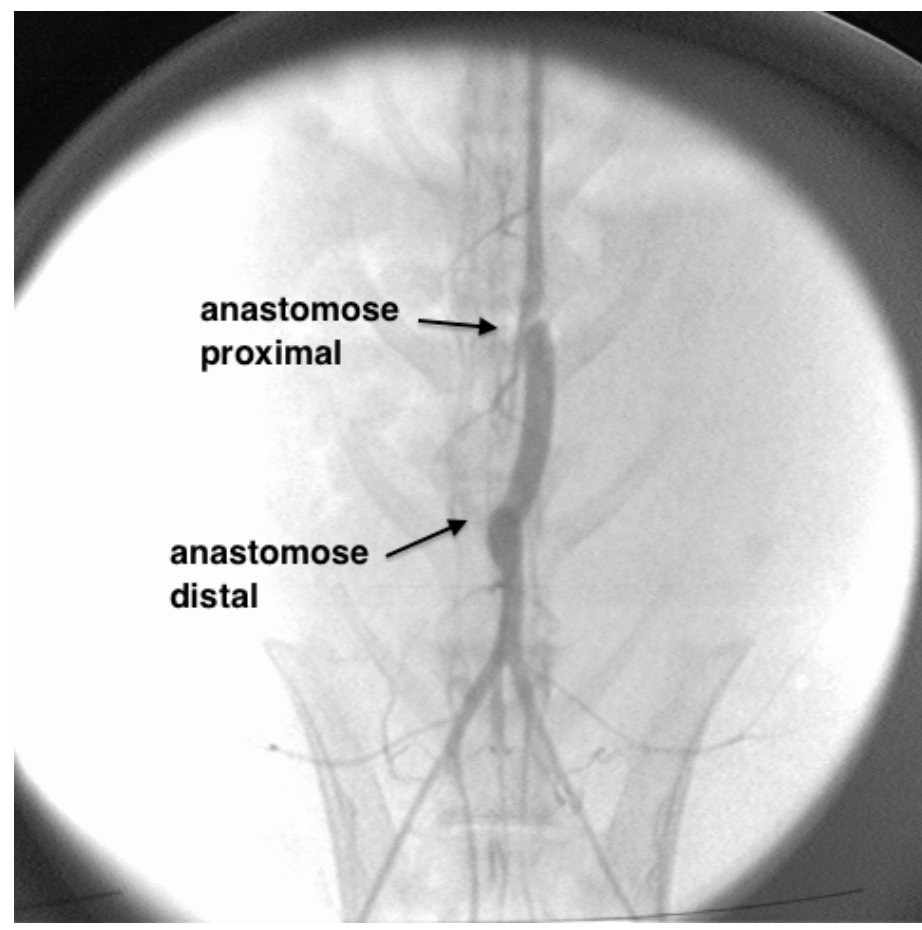

Figura 15 - Angiografia da aorta após 55 dias do implante de prótese de PDMS, com estenose de $23 \%$ na anastomose proximal. 


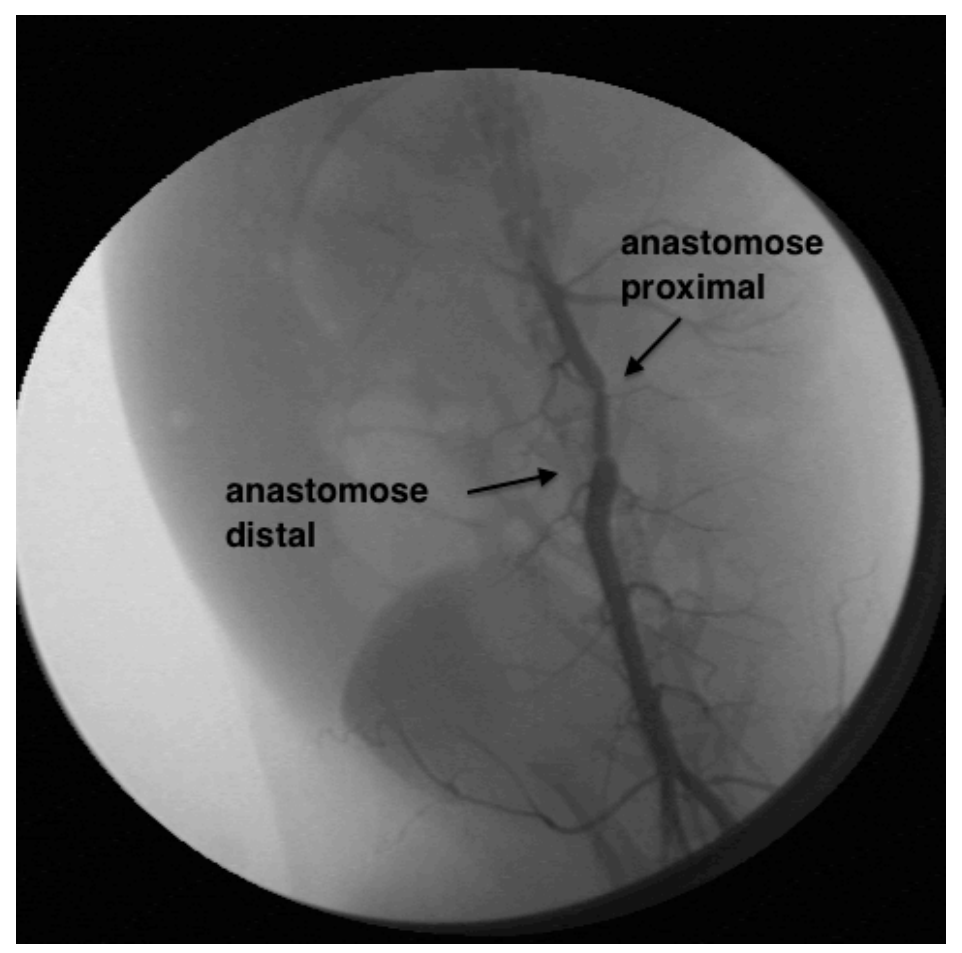

Figura 16 - Angiografia da aorta após 79 dias do implante de prótese de PDMS, com estenose de $50 \%$ nas anastomoses proximal e distal.

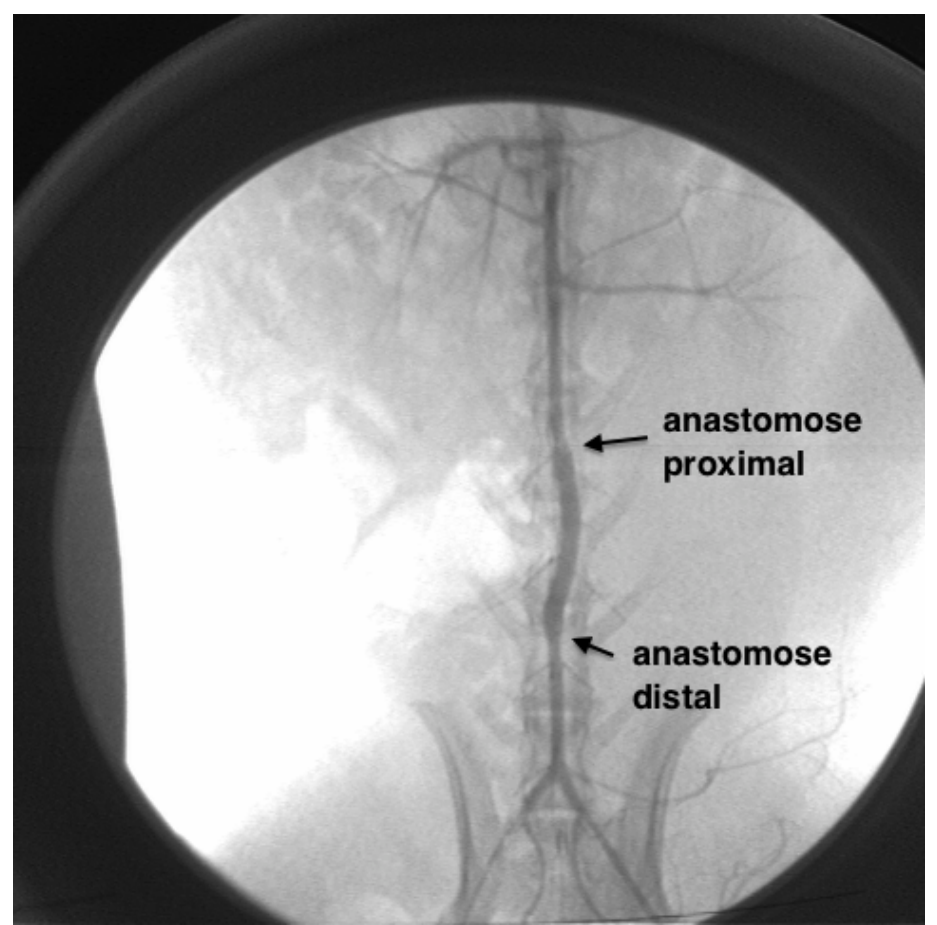

Figura 17 - Angiografia da aorta após 80 dias do implante de prótese de PTFE, apresentando estenose de $10 \%$ na anastomose proximal. 


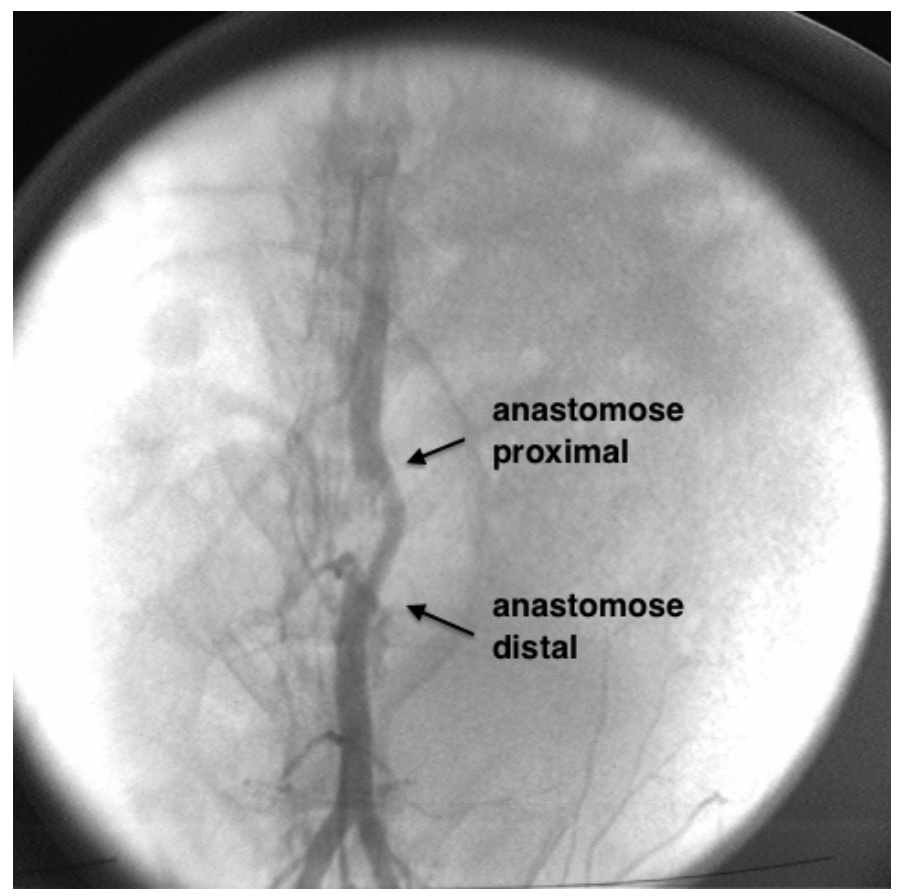

Figura 18 - Angiografia da aorta após 90 dias do implante de prótese de PTFE, sem estenoses.

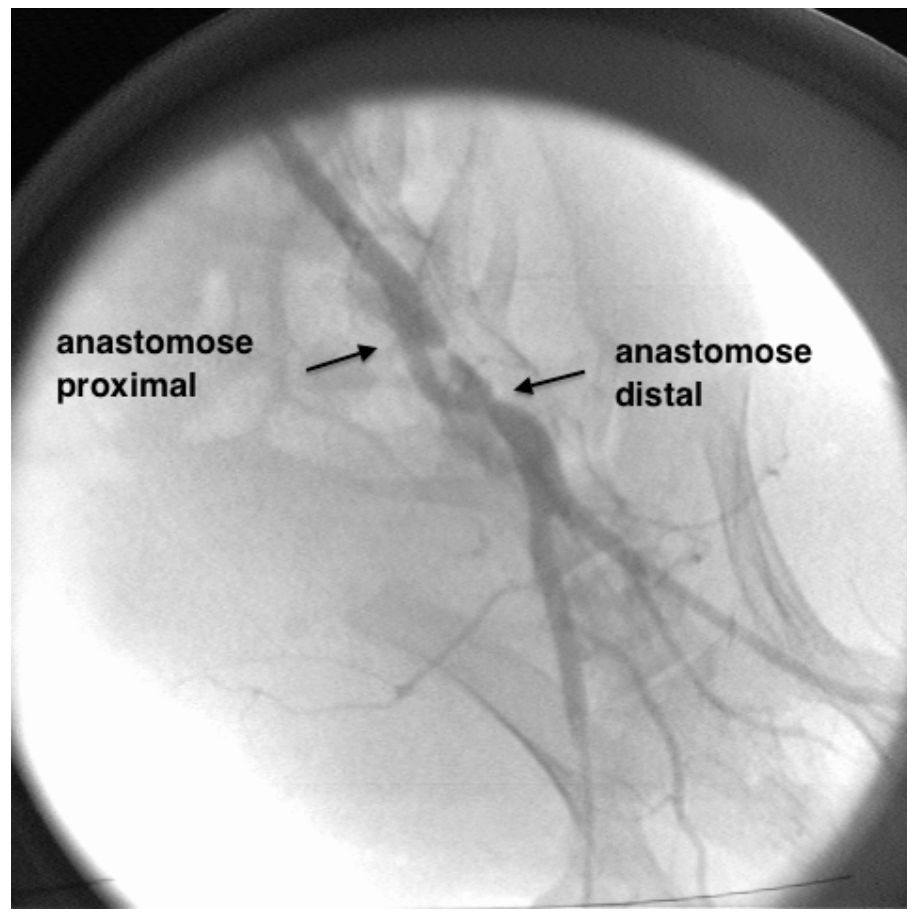

Figura 19 - Angiografia da aorta após 70 dias do implante de prótese de PTFE, com estenose estimada em $25 \%$ na anastomose distal. 
Gráfico 9 - Grau de estenose, segundo o grupo de estudo

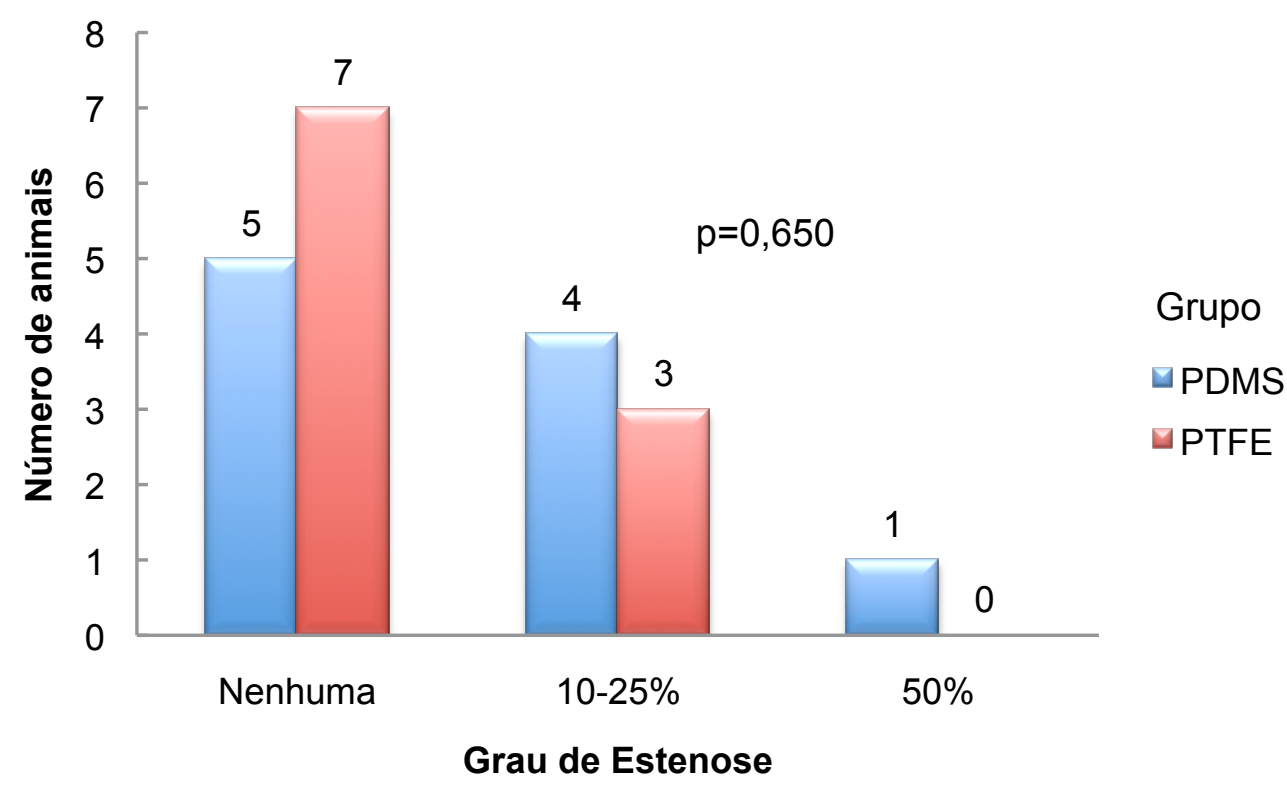

\subsection{Análise do implante das próteses}

A prótese de PDMS apresentou elasticidade, complacência e facilidade de manuseio, principalmente no momento de suturá-la à artéria receptora. A agulha penetrou facilmente a parede da prótese, que se moldou bem à parede da artéria nativa. Além disso, a prótese apresentou facilidade de palpação de pulso sobre a mesma. A colocação de clamps na prótese de PDMS não causou nenhuma deformidade, sendo que após retirada dos mesmos, a prótese retomava seu formato tubular.

A prótese de PTFE possui pouca elasticidade e paredes mais rígidas, o que fez com que a agulha penetrasse a mesma com mais dificuldade e a sutura fosse mais trabalhosa. Além disso, esse tipo de prótese não se 
acomodava tão bem à artéria nativa quanto as próteses de PDMS devido à rigidez de suas paredes. Outra característica observada foi o frequente sangramento pelo orifício de passagem da agulha no PTFE, o que não ocorreu nas próteses de PDMS. A colocação de clamps nesse tipo de prótese fez com que suas paredes ficassem marcadas e permanecessem com certa deformação inicial, mas que podia ser corrigida manualmente.

\subsection{Análise macroscópica}

Não houve nenhum caso de infecção ou formação de pseudoaneurisma nas linhas de sutura em ambos os grupos. As próteses de PDMS não sofreram dilatação aneurismática.

Observando-se a reação tecidual externa do organismo na região do implante, foi constatado que as duas próteses estavam envolvidas por um tecido fibroso cicatricial. As próteses de PTFE apresentaram-se mais aderidas, com um tecido de incorporação mais espesso, o que resultou em maior dificuldade na identificação do plano de clivagem com o tubo e na remoção do mesmo para posterior análise microscópica. As próteses de PDMS apresentaram reação tecidual mais discreta, com um tecido de incorporação mais delicado, o que permitiu que a retirada da peça fosse realizada mais facilmente, uma vez que o plano de clivagem foi identificado e dissecado com facilidade. 
Foi também observado, na região interna das próteses, que as linhas de sutura eram recobertas por tecido brilhante, contínuo ao endotélio da artéria nativa (Figuras 20 e 21).

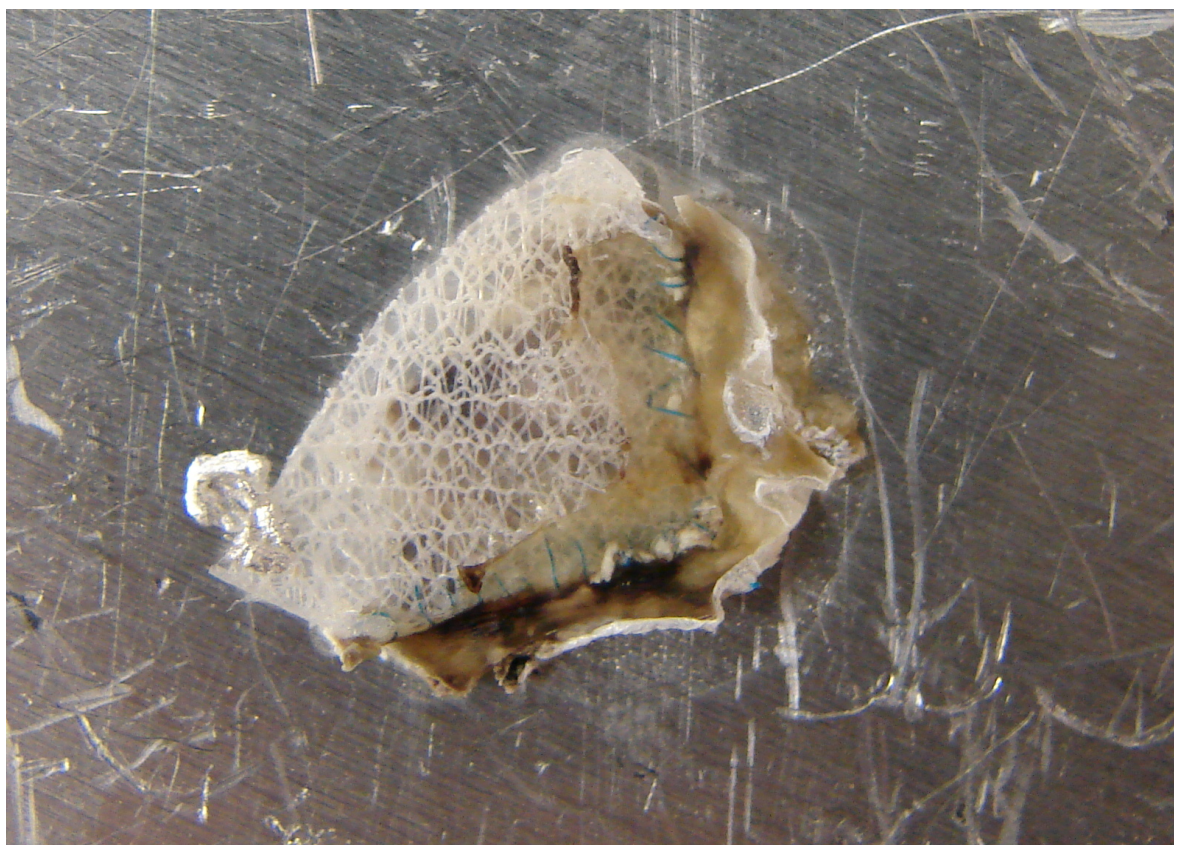

Figura 20 - Secção longitudinal da anastomose proximal da prótese de PDMS (notar neoíntima na região da linha de sutura). 


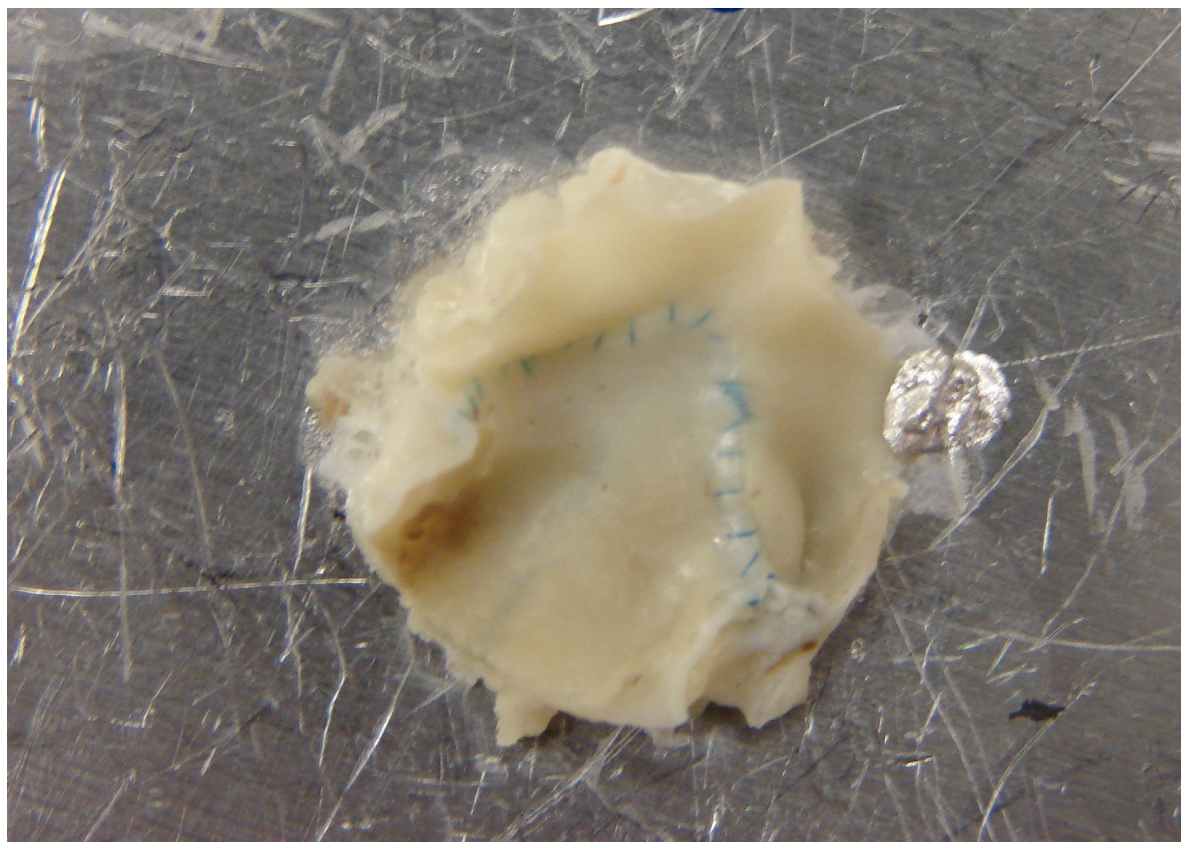

Figura 21 - Secção longitudinal da anastomose proximal da prótese de PTFE (notar neoíntima na região da linha de sutura).

\subsection{Microscopia eletrônica}

À microscopia eletrônica, nos dois tipos de prótese, observou-se a formação de uma camada de neoíntima bem caracterizada, que recobria as linhas de sutura, como pode-se observar nas figuras 22 a 24 . A neoíntima formada recobria a região das anastomoses e crescia apenas alguns milímetros além, não sendo constatada endotelização completa da superfície interna em nenhuma das próteses (Figuras 25). Em alguns casos foi possível observar um crescimento endotelial mais exuberante, correspondendo à hiperplasia intima (Figura 26). 


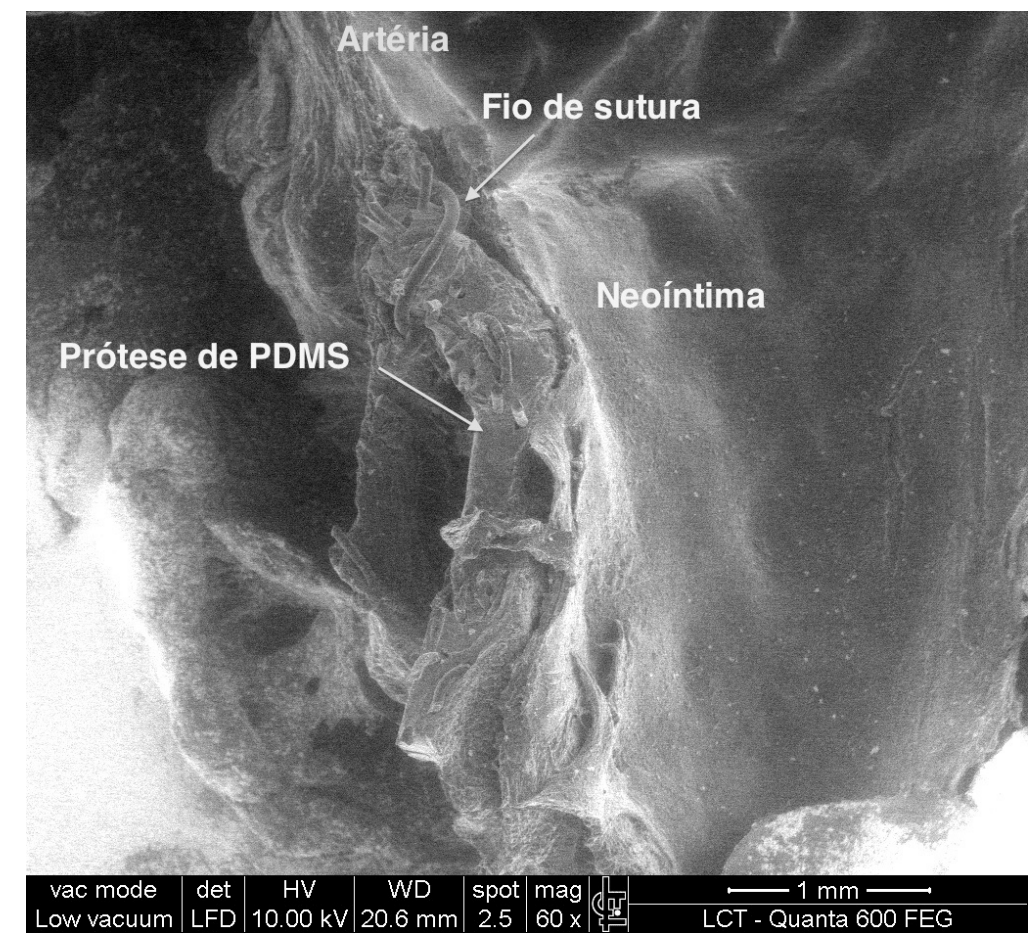

Figura 22 - Aspecto da microscopia eletrônica da prótese de PDMS recoberta pela neoíntima na região da anastomose.

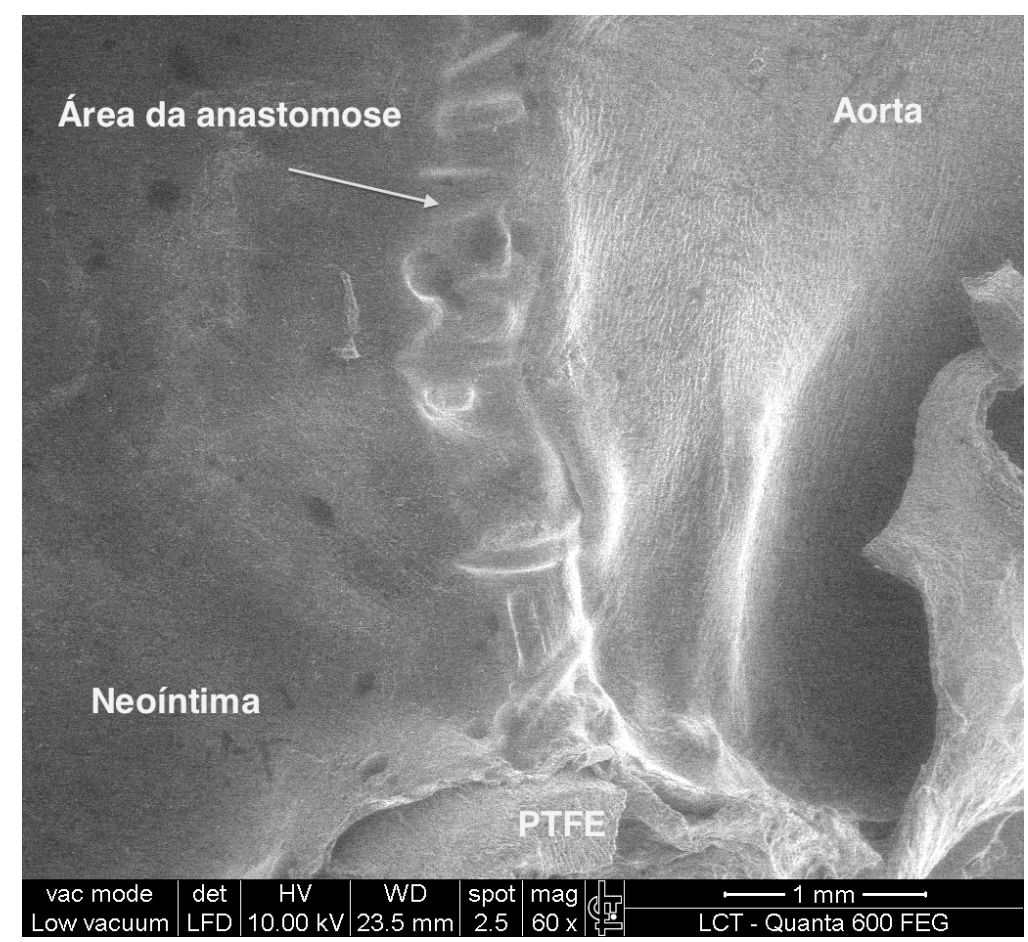

Figura 23 - Aspecto da microscopia eletrônica da prótese de PTFE recoberta pela neoíntima em região próxima à anastomose. 


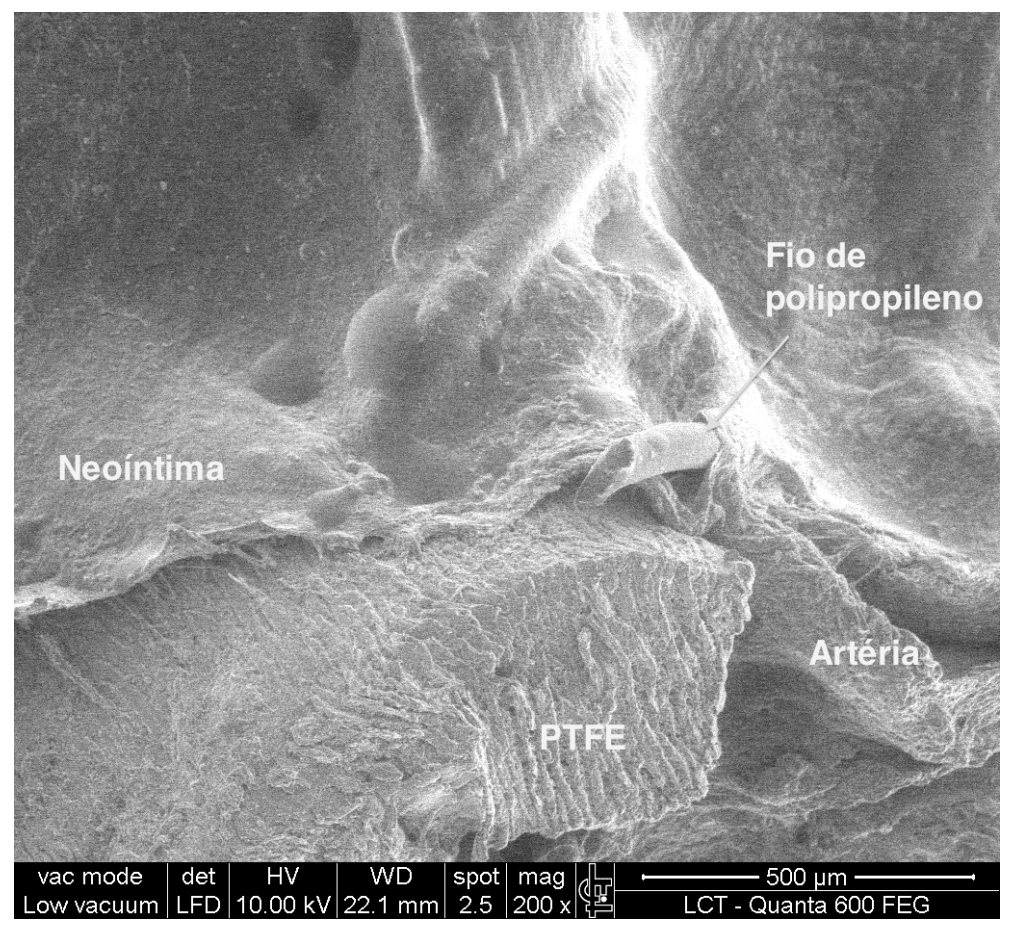

Figura 24 - Região da anastomose com prótese de PTFE (observar fio de sutura e toda região anastomótica recobertos).

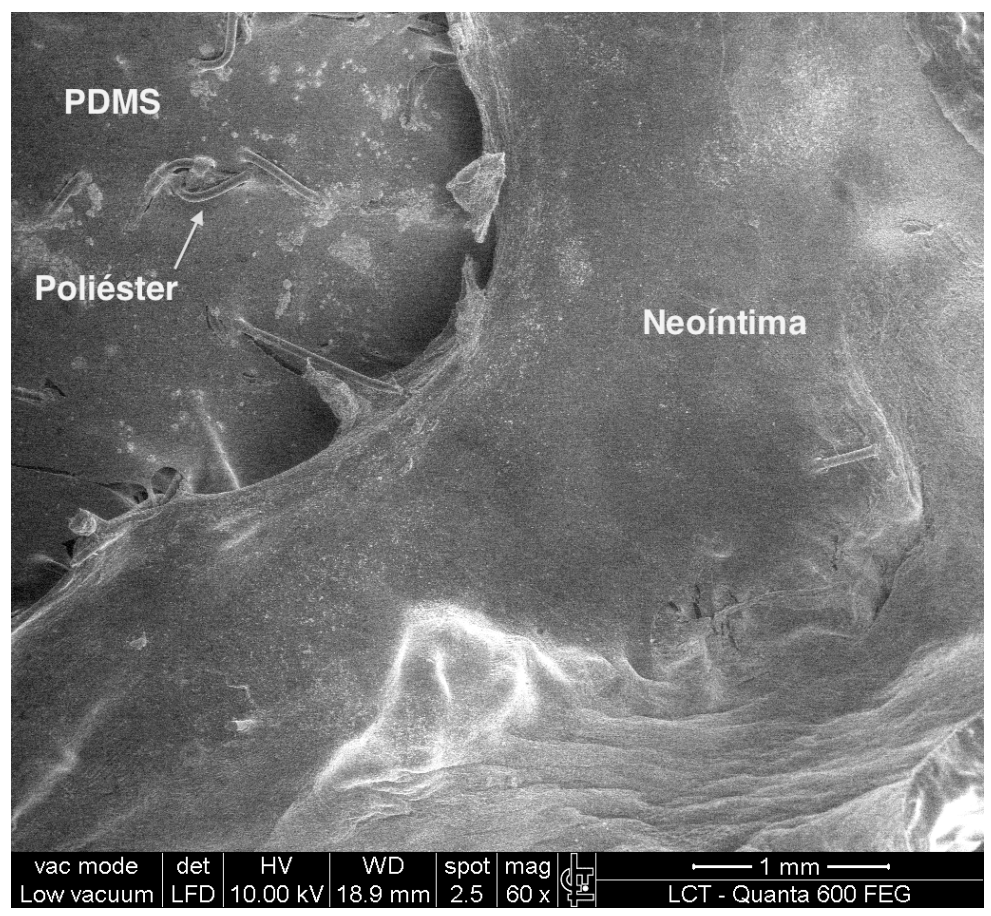

Figura 25 - Microscopia eletrônica da região onde ocorre o final da progressão do endotélio (notar no quadrante superior esquerdo a prótese de PDMS não recoberta). 


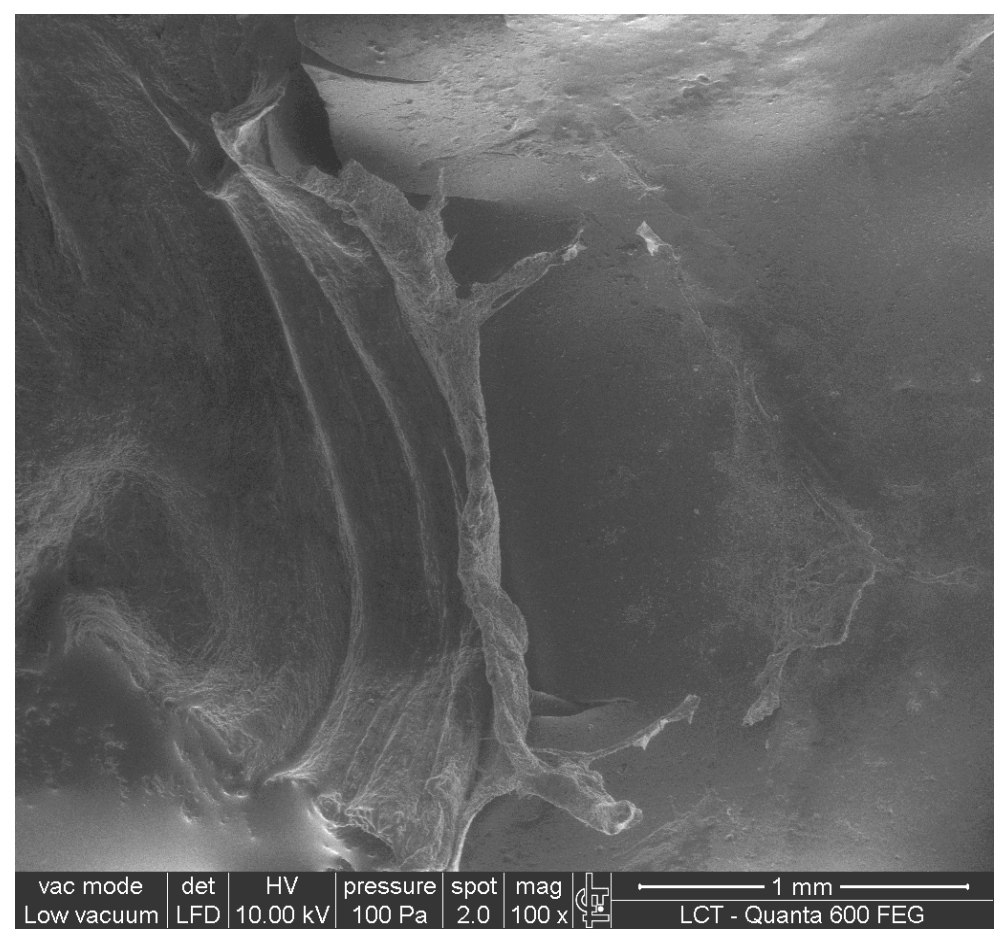

Figura 26 - Linha de sutura da prótese de PDMS após 82 dias do implante, com crescimento exuberante do endotélio junto à região da anastomose (hiperplasia intimal). 
5. DISCUSSÃO 
Ainda que os enxertos autólogos arteriais ou venosos representem a aproximação do substituto vascular ideal e proporcionem os melhores resultados nas reconstruções vasculares, sabe-se que tais enxertos nem sempre estão disponíveis ou são adequados, muitas vezes porque já foram utilizados, em outros casos por extração prévia em uma cirurgia para tratamento de varizes, por serem veias de fino calibre ou que já sofreram tromboflebite ou por existirem riscos de complicações associadas à retirada da veia. Por estas razões, faz-se necessária a opção por um substituto sintético, o que sustenta o interesse da pesquisa neste campo da cirurgia vascular ${ }^{4}$.

As próteses sintéticas disponíveis, fabricadas em PTFE ou Dacron, funcionam satisfatoriamente em territórios de alto fluxo e baixa resistência, mas não são adequadas para artérias de pequeno calibre $(<6 \mathrm{~mm})$, especialmente quando a anastomose distal é abaixo do joelho. Nessas condições, as referidas próteses tendem a induzir trombose, embolismo, estenose e oclusão, além de poderem alojar bactérias (resultando em infecção do enxerto) e funcionar como um corpo estranho no organismo do paciente $^{70,71}$. Próteses vasculares sintéticas também estão associadas à baixa complacência e à hiperplasia intimal especialmente nas áreas das anastomoses ${ }^{70}$. A hiperplasia intimal é considerada o principal fator limitante da durabilidade de um enxerto e resulta em taxas significativas de morbidade, reintervenções e perda de membros ${ }^{72,73}$. 
Diante da realidade atual quanto às próteses sintéticas para vasos de pequeno calibre, foi desenvolvido um novo substituto arterial por De Luccia e De Luccia ${ }^{66}$, fabricado a partir do polidimetilsiloxano, conhecido com silicone, com reforço de tecido de poliéster. O silicone foi escolhido devido ao fato de ser um material de ampla utilização no meio médico e por possuir diversas das características consideradas importantes para um substituto vascular, como baixa toxicidade, baixa trombogenicidade, biocompatibilidade $\mathrm{e}$ bioestabilidade ${ }^{25,42-50}$. O reforço com tecido de poliéster foi utilizado com objetivo de aumentar a resistência física das paredes das próteses de silicone, prevenindo assim a ocorrência de dilatações e também de rasgos; objetivo esse que foi alcançado, uma vez que não ocorreu nenhum caso de dilatação ou pseudoaneurisma no período de observação; assim como nenhum rasgo durante a realização das anastomoses. Pelo fato do PTFE ser o enxerto sintético mais utilizado atualmente para as revascularizações de artérias de pequeno calibre na região infragenicular, o mesmo foi escolhido para a comparação com a nova prótese.

A fase pré-clínica em animais é necessária para pesquisas de novas próteses vasculares, a fim de avaliar a capacidade do novo material em manter adequadamente a fisiologia do sistema circulatório e para determinar a resposta do hospedeiro e, também, da própria prótese ao implante ${ }^{6}$. Essa fase de estudo também é exigida para a aprovação de órgãos reguladores, conforme descrito nas normas publicadas para fabricantes de enxertos reconhecidas pelo FDA americano ${ }^{74}$. 
No que diz respeito a modelos animais para estudo de próteses vasculares, podemos encontrar diversas opções na literatura como cães, primatas (babuínos), porcos, coelhos, carneiros, ratos e camundongos. Animais grandes e pequenos têm suas próprias vantagens e desvantagens.

Para a escolha do modelo animal ideal devem ser levados em consideração o sitio das anastomoses, calibre e comprimento da prótese e duração do tempo de seguimento. Custos, disponibilidade, facilidade de manuseio durante os procedimentos, resposta e tolerância à cirurgia e à anestesia, tamanho da artéria e intensidade de fluxo nos locais de implante da prótese também são fatores utilizados para a escolha do animal a ser utilizado; entretanto, é essencial que o modelo animal selecionado simule corretamente o aspecto relevante da fisiologia humana que está sendo avaliado ${ }^{4}$

O modelo canino foi o mais utilizado por muito tempo, por possuir uma série de vantagens: são animais acostumados ao convívio com seres humanos e assim são de manuseio fácil e sua manutenção não é considerada cara ou trabalhosa; além disso, a fisiologia cardiovascular canina é similar à dos humanos, os vasos são de fácil acesso cirúrgico, há disponibilidade de artérias periféricas de 3 a $5 \mathrm{~mm}$, a aorta pode acomodar interposição de enxertos de até $8 \mathrm{~mm}$, e são animais que toleram bem anestesia e procedimentos cirúrgicos prolongados ${ }^{4}$. Alguns autores descrevem que o comportamento das próteses nos cães é o que mais se assemelha ao dos humanos, o que explica a sua preferência como o modelo 
animal para avaliação de enxertos vasculares ${ }^{75,76}$. Entretanto, seu uso foi bastante reduzido devido a reivindicações de ativistas de direitos animais ${ }^{6}$.

$\mathrm{Na}$ fase piloto da linha de pesquisa da qual este projeto faz parte, foi utilizado o modelo porcino. Tal modelo apresenta aspectos favoráveis e desfavoráveis. Os porcos apresentam similaridades com a anatomia e a fisiologia vascular humanas, com um sistema de coagulação muito parecido com o humano, porém com tendência a hipercoagulabilidade ${ }^{4}$. Entretanto, o modelo animal porcino apresentou peculiaridades que motivaram a mudança do modelo experimental: esses animais apresentam uma resposta imune exagerada aos enxertos, muitas vezes resultando em hiperplasia intimal exuberante; além disso, têm rápido crescimento e ganho de peso em curto prazo, o que representava dificuldade operacional importante na fase do retorno para cateterismo e retirada das peças; outro fator que fez com que os porcos fossem substituídos por coelhos foi devido à manutenção dos animais que, obrigatoriamente, deveria ser feita em biotério fora do perímetro urbano da cidade de São Paulo, de acordo com o Art. $25^{\circ}$. da Lei Municipal $n^{\text {o. }} 10309$ de 22/04/1980.

Diante do exposto, o projeto foi alterado para o implante das próteses na aorta de coelhos. O modelo cunicular é considerado como um bom modelo para a avaliação de enxertos para vasos de pequeno calibre ${ }^{77}$, e como ideal para o estudo de próteses de calibre entre $1 \mathrm{e} 4 \mathrm{~mm}^{4}$. A fisiologia vascular dos coelhos assemelha-se em muitos aspectos à humana, incluindo as taxas de trombogenicidade, patência e endotelização ${ }^{4,77}$. Porém, assim 
como os demais modelos, esse também apresenta vantagens e desvantagens.

No que se refere às vantagens do uso do modelo cunicular, pode-se citar a disponibilidade desses animais, que foram fornecidos pelo próprio biotério da Faculdade de Medicina da USP. Além disso, animais de pequeno porte como coelhos são de fácil manuseio e apresentam problemas logísticos e financeiros mínimos. Outra vantagem refere-se ao pequeno espaço físico necessário para acomodá-los e a facilidade de manutenção no período pós-operatório. O menor custo deste modelo, quando comparado ao modelo suíno, é bastante relevante. Esses animais apresentam também grande similaridade com os mecanismos de hemostasia humanos, incluindo o sistema de coagulação, com artérias com propriedades tromboplásticas e fibrinolíticas semelhantes ${ }^{4}$.

Dentre as desvantagens do modelo utilizado, podem ser citadas a dificuldade de intubação orotraqueal e a fragilidade dos animais à anestesia e à manipulação cirúrgica.

Coelhos são animais de difícil intubação orotraqueal ${ }^{67}$, até mesmo para médicos veterinários experientes ${ }^{78}$. O procedimento é considerado um desafio devido a uma série de fatores: pequena abertura da boca, cavidade oral e orofaringe estreitas, dentes incisivos longos, a língua volumosa e a glote pequena que dificultam a visualização da laringe que, por sua vez, é pequena; os animais também podem sofrer laringoespasmo desencadeado apenas à tentativa da intubação; além de lesões iatrogênicas da mucosa 
respiratória, que podem resultar em sequelas graves no período pósoperatório, incluindo necrose da mesma, com obstrução de vias aéreas e óbito $^{67,78,79}$. Há descrição de intubação com laringoscópio de lâmina reta ${ }^{67}$ e também às $\operatorname{cegas}^{78,79}$, porém nossa equipe não teve sucesso na realização do procedimento, mesmo após diversas tentativas. Devido a isso, as cirurgias foram realizadas com os animais ventilando espontaneamente e com cateter de oxigênio.

A fragilidade dos animais à manipulação cirúrgica pôde ser identificada pelo elevado número de animais $(n=15)$ com complicações (óbito e paraplegia) no presente estudo. A comparação entre os grupos quanto à evolução com complicações no período pós-operatório $(p=0,526)$ não resultou em diferença estatística significativa; o que demonstra que as complicações ocorreram independentemente do tipo de prótese utilizada.

A mortalidade geral dos animais desse estudo foi de $20 \%$ (8/40), sendo que não houve diferença entre os grupos com relação à mortalidade $(p=0,695)$. A morte desses animais pode ter sido secundária a erros técnicos transoperatórios, repercussão do tempo de clampeamento aórtico ou por hemorragia, apesar de todos os animais terem suas paredes abdominais fechadas somente após verificação de hemostasia adequada. Não foi realizada nenhuma necrópsia ou arteriografia nesses animais.

A escolha do implante dos enxertos em posição aórtica foi realizada a fim de minimizar a desproporção de calibre das próteses com a artéria nativa. A escolha pelas anastomoses do tipo término-lateral foi feita com o 
objetivo de acomodar melhor as próteses à aorta; além disso, o uso dessa técnica permitiu que os animais fossem submetidos ao pré-condicionamento isquêmico, com a intenção de minimizar a ocorrência de paraplegia no pósoperatório. Sabe-se que esse tipo de anastomose está relacionado a taxas mais elevadas de hiperplasia intimal devido à maior tensão de cisalhamento (força que o fluxo sanguíneo exerce sobre as paredes do vaso ou da prótese); porém as suturas nessa modalidade tiveram execução e resultados muito melhores do que as suturas término-terminais realizadas na fase piloto do estudo. Além disso, o aumento da hiperplasia intimal nessa modalidade de anastomose é mais descrito com o uso de veias do que com próteses sintéticas, uma vez que nessas o fluxo sanguíneo tende a ser menos turbulento e mais laminar ${ }^{80}$.

O clampeamento da aorta infrarrenal predispôs à ocorrência de paraplegia nos animais pela lesão neurológica secundária à isquemia causada pela perfusão inadequada da artéria espinhal. Sabe-se que a paraplegia por isquemia medular em cirurgias com clampeamento aórtico pode ocorrer por tempo prolongado de uso dos clamps, pela ligadura ou lesão de artérias lombares ou trombose aguda da aorta ${ }^{81}$. Não houve diferença entre os grupos quanto à evolução com paraplegia $(p=1)$.

Neste estudo, o tempo médio de clampeamento da aorta foi de 52,92 minutos, sendo de 50,7 minutos no grupo do PDMS e 55,26 no grupo do PTFE, não havendo diferença significativa dos tempos de clampeamento entre os grupos $(p=0,299)$, o que sugere que a prótese de PDMS é 
comparável ao PTFE na realização do implante cirúrgico da mesma em coelhos.

Avaliando-se o tempo de clampeamento da aorta e a ocorrência de complicações (paraplegia e óbito) no grupo total de animais do estudo, não foi encontrada relação entre os mesmos; isto é, não houve diferença estatística significativa entre os tempo de clampeamento entre animais que evoluíram com e sem complicações $(p=0,264)$. Também não houve diferença significativa do tempo de clampeamento entre os animais com e sem complicações em cada grupo $(p=0,581)$. Tempos de clampeamento mais prolongados não puderam ser relacionados à ocorrência de óbito ou paraplegia em nenhum dos grupos.

Em estudo publicado em 1994, por Wisselink et al. ${ }^{82}$, as taxas de paraplegia em coelhos foram descritas em $90 \%$ após 21 minutos de clampeamento aórtico; e de $100 \%$ após 30 minutos. A diferença tão importante entre a publicação citada e os resultados desta pesquisa pode ser justificada pela realização do pré-condicionamento isquêmico, que confere uma maior resistência à isquemia a órgãos submetidos previamente à interrupção temporária e curta do suprimento sanguíneo.

O mecanismo pelo qual uma agressão isquêmica prévia protege o órgão de uma agressão mais intensa posterior ainda não é bem estabelecido, mas o pré-condicionamento isquêmico parece estar associado a uma redução no estresse oxidativo, na apoptose, na adesão leucocitária e na conversão de xantina desidrogenase em xantina oxidase ${ }^{83,84}$. 
Como já citado anteriormente, a trombose aguda da aorta também pode levar à paraplegia, mas no presente estudo não foi possível estabelecer a relação entre oclusão da prótese e paraplegia. No grupo do PDMS, foram realizados apenas três cateterismos em animais paraplégicos, dos quais dois apresentavam oclusão e em um o enxerto estava patente. No grupo do PTFE, o cateterismo foi realizado nos cinco animais que ficaram paraplégicos: em três as próteses estavam ocluídas, enquanto que nos outros dois animais as próteses apresentavam-se patentes. A paraplegia dos três animais com próteses patentes pode ter ocorrido pelo tempo de clampeamento ou pela ligadura de artérias lombares.

A oclusão de próteses também não apresentou relação com o tempo de clampeamento. Não foi observada diferença significativa quanto ao tempo de clampeamento entre os animais com prótese na condição patente ou ocluída $(p=0,587)$, assim como não houve diferença significativa no tempo de clampeamento entre os animais que evoluíram com patência ou oclusão da prótese dentro de cada grupo $(p=0,851)$.

Sabe-se que a trombose precoce (até 30 dias) de próteses vasculares geralmente ocorre por falhas técnicas na confecção do enxerto (erro técnico na realização da anastomose, erro de posição ou acotovelamento da prótese ou deficiência de escoamento), seleção inadequada do paciente ou da técnica empregada. As oclusões a médio prazo estão associadas frequentemente à hiperplasia intimal nas regiões perianastomóticas, sendo essa reconhecida como a principal causa de 
oclusão de enxertos vasculares entre 1 e 24 meses após uma cirurgia de revascularização. As oclusões tardias (acima de 2 anos) devem-se usualmente à progressão da doença aterosclerótica na região proximal e/ou distal ao sitio operado ${ }^{69,72,85}$. Sendo assim, as tromboses precoces, em ambos os grupos, foram atribuídas a falhas técnicas na confecção dos enxertos, motivo pelo qual esses animais foram excluídos da análise de patência. Foram observadas 2 próteses ocluídas precocemente em cateterismos de animais do grupo do PDMS, e em 3 do grupo do PTFE.

Nos animais em que a oclusão ocorreu tardiamente (4 do grupo do PDMS e 1 do grupo do PTFE), não ocorreu nenhum caso de paraplegia e a oclusão dessas próteses foi diagnosticada somente ao exame angiográfico, uma vez que esses animais não apresentaram nenhum sinal clínico. Nesses coelhos, observou-se exuberante circulação colateral nas aortografias, o que leva à conclusão que a oclusão não ocorreu subitamente e sim de forma lenta e gradual, provavelmente devido à hiperplasia intimal.

Para a avaliação da patência e do grau de estenose das próteses, foram realizados exames de arteriografia retrógrada por fluoroscopia, através da injeção de contraste iodado pela artéria femoral dos animais, após período mínimo de 28 dias (conforme já citado anteriormente, oclusões antes desse tempo são atribuídas a falhas cirúrgicas). Foram realizados cateterismos com até 108 dias no grupo do PDMS e 90 dias no grupo do PTFE. A taxa de patência das próteses de PDMS foi de 100\% em 30 dias, $92,3 \%( \pm 7,4)$ em 60 dias e de $73,8 \%( \pm 13,1)$ em 90 dias. No grupo das 
próteses de PTFE, a patência em 30 dias foi de $100 \%$, e em 60 e 90 dias foi de $87,5 \%( \pm 11,7)$. A análise comparativa entre os grupos com relação à patência das próteses não demonstrou significância estatística $(p=0,62)$. As taxas de patência obtidas neste trabalho são comparáveis a algumas publicações encontradas na literatura, como de Nordestgaard et $a l .{ }^{43}$ que apresentaram trabalho em que realizavam implante de próteses de PTFE de $3 \mathrm{~mm}$ na aorta de coelhos, com taxa de patência de $92 \%$ em 90 dias.

As próteses patentes foram avaliadas com relação ao grau de estenose através da relação entre a medida do menor diâmetro da luz da prótese em relação ao diâmetro da luz dos segmentos proximal e distal da aorta de cada animal. Não foi encontrada nenhuma estenose com repercussões hemodinâmicas, uma vez que em nenhum dos grupos foi encontrada estenose maior que $50 \%$. Os grupos não apresentaram diferença significativa quanto ao grau de estenose das próteses $(p=0,650)$; 0 que, mais uma vez, demonstra que a prótese de PDMS apresenta comportamento semelhante ao do PTFE.

A redução do diâmetro luminal nos casos com estenose foi atribuída à formação da neoíntima, uma vez que o trauma arterial numa cirurgia de revascularização induz à resposta cicatricial a fim de otimizar a interação entre o novo conduto arterial e o fluxo sanguíneo na superfície interna (endotelização), e com os tecidos circundantes ${ }^{86}$. Como parte dessa resposta ocorrem proliferação celular, além de produção e depósito de matriz extracelular, resultando no espessamento intimal composto por 
células musculares lisas, colágeno, elastina e proteoglicanos. As células musculares lisas sofrem proliferação na camada média do vaso e migram para a íntima. Em cirurgias de revascularização arterial, essas células migram da artéria nativa para a superfície interna da prótese ou da veia ${ }^{87,88}$, o que foi possível de ser visualizado nos exames de microscopia eletrônica.

Os resultados obtidos ratificam a biocompatibilidade já descrita do silicone, material esse muito utilizado em implantes em seres humanos com outras finalidades há bastante tempo. A prótese de PDMS apresenta ainda a característica de biomaterial, ou seja, é um material sintético usado para substituir parte de um sistema vivo ou para funcionar em íntimo contato com um tecido vivo. Pelas características de cura do silicone, a estrutura do tubo tem complacência que o tornou flexível, pulsátil e adequado ao manuseio e às suturas. Já as próteses de PTFE possuem paredes mais rígidas e de pouca elasticidade, resultando em maior dificuldade na penetração da agulha durante a sutura e, consequentemente, na confecção da anastomose. Também pelas características do PTFE, tais próteses não se moldavam tão bem à artéria nativa quanto as de PDMS.

A reação cicatricial ao redor das próteses mostrou-se menos intensa no grupo do PDMS, com um tecido menos fibroso e mais fino, o que permitiu que essas próteses fossem removidas mais facilmente do que as próteses de PTFE; reforça-se assim a afirmação de que o silicone é um material inerte e biocompatível. 
Apesar da endotelização completa de um enxerto sintético ser muito almejada na pesquisa desse campo da Cirurgia Vascular, não há descrição de nenhum material com capacidade de estimular o crescimento endotelial por toda sua extensão em humanos ${ }^{89,90}$. Sabe-se que o crescimento endotelial transanastomótico não excede mais que 1 a $2 \mathrm{~cm}$ mesmo após anos do implante ${ }^{91,92}$. À microscopia eletrônica, realizada de maneira amostral na presente pesquisa, observou-se a formação de camada de neoíntima nas regiões perianastomóticas, crescendo a partir do endotélio da artéria nativa, não sendo observada endotelização completa da superfície interna em nenhuma das próteses. 


\section{CONCLUSÃO}


Nas condições da presente pesquisa, pôde-se concluir que:

1. Não houve diferença entre a prótese de PDMS e de PTFE quanto às taxas de patência e estenose.

2. As próteses de PDMS apresentaram melhor elasticidade, adaptabilidade, complacência e facilidade no manuseio quando comparadas ao PTFE, no modelo experimental em coelhos.

3. Não foi evidenciada diferença entre as complicações pós-operatórias (paraplegia e óbito) do uso das próteses de PDMS e de próteses de PTFE.

4. Tanto as próteses de PDMS como de PTFE mostraram-se biocompatíveis no sistema arterial do coelho, apresentando adequada integracão tecidual e crescimento de neoíntima apenas nas regiões das anastomoses. Não houve endotelização completa em nenhuma das próteses. 
7. REFERÊNCIAS 
1. Wang $X$, Lin $P$, Yao Q, Chen C. Development of small-diameter vascular grafts. World J Surg. 2007;31(4):682-9.

2. Venkatraman S, Boey F, Lao LL. Implanted cardiovascular polymers: Natural, synthetic and bio-inspired. Prog Polym Sci. 2008;33(9):85374.

3. Kakisis JD, Liapis CD, Breuer C, Sumpio BE. Artificial blood vessel: the Holy Grail of peripheral vascular surgery. J Vasc Surg. 2005;41(2):349-54.

4. Byrom MJ, Bannon PG, White GH, Ng MKC. Animal models for the assessment of novel vascular conduits. J Vasc Surg. 2010;52(1):17695.

5. Conte MS. The ideal small arterial substitute: a search for the Holy Grail? FASEB J. 1998;12(1):43-5.

6. Abbott WM, Callow A, Moore W, Rutherford R, Veith F, Weinberg S. Evaluation and performance standards for arterial prostheses. $J$ Vasc Surg. 1993;17:746-56.

7. Teebken OE, Haverich A. Tissue engineering of small diameter vascular grafts. Eur J Vasc Endovasc Surg. 2002;23:475-85.

8. Schmedlen RH, Elbjeirami WM, Gobin AS, West JL. Tissue engineered small-diameter vascular grafts. Clin Plast Surg. 2003;30(4):507-17.

9. Norgren L, Hiatt WR, Dormandy JA, Nehler MR, Harris KA, Fowkes FGR. Inter-Society Consensus for the Management of Peripheral Arterial Disease (TASC II). J Vasc Surg. 2007;45 Suppl S(1):S5-67.

10. Hufnagel CA. Permanent intubation of the thoracic aorta. Arch Surg. 1947;54(4):382-9.

11. Donovant TJ, Zimmermann B. The effect of artificial surfaces on blood coagulability, with special reference to polyethylene. Blood. 1949;4(12):1310-6.

12. Moore HD. The replacement of blood vessels by polythene tubes. Surg Gynecol Obstet. 1950;91(5):593-600.

13. Blakemore $A H$, Voorhees $A B$. The use of tubes constructed from vinyon $\mathrm{N}$ cloth in bridging arterial defects; experimental and clinical. Ann Surg. 1954;140(3):324-34. 
14. Voorhees $A B$, Jaretzki $A$, Blakemore $A$. The use of tubes constructed from vinyon "N" cloth in bridging arterial defects. Ann Surg. 1952;135(3):332-6.

15. Salacinski HJ, Goldner S, Giudiceandrea A, Hamilton G, Seifalian AM, Edwards $A$, et al. The mechanical behavior of vascular grafts: a review. J Biomater Appl. 2001;15(3):241-78.

16. Kannan RY, Salacinski HJ, Butler PE, Hamilton G, Seifalian AM. Current status of prosthetic bypass grafts: a review. J Biomed Mater Res B Appl Biomater. 2005 Jul;74(1):570-81.

17. Wise SG, Byrom MJ, Waterhouse A, Bannon PG, Weiss AS, Ng MKC. A multilayered synthetic human elastin/polycaprolactone hybrid vascular graft with tailored mechanical properties. Acta Biomater. 2011;7(1):295-303.

18. EGDAHL RH. Silicone rubber as aortic grafting material. AMA Arch Surg. 1955;71(5):694-6.

19. Lau $\mathrm{H}$, Cheng SW. Is the preferential use of ePTFE grafts in femorofemoral bypass justified? Ann Vasc Surg. 2001;15(3):383-7.

20. Miller JH, Foreman RK, Ferguson L, Faris I. Interposition vein cuff for anastomosis of prosthesis to small artery. Aust N Z J Surg]. 1984 Jun;54(3):283-5.

21. Paty PS, Shah DM, Saifi J, Chang BB, Feustel PJ, Kaufman JL, et al. Remote distal arteriovenous fistula to improve infrapopliteal bypass patency. J Vasc Surg. 1990;11(1):171-7.

22. Shi Q, Wu MH, Hayashida N, Wechezak AR, Clowes AW, Sauvage LR. Proof of fallout endothelialization of impervious Dacron grafts in the aorta and inferior vena cava of the dog. J Vasc Surg. 1994;20(4):54656.

23. Sala F, Hassen-Khodja R, Lecis A, Bouillanne P-J, Declemy S, Batt M. Long-term outcome of femoral above-knee popliteal artery bypass using autologous saphenous vein versus expanded polytetrafluoroethylene grafts. Ann Vasc Surg. 2003;17(4):401-7.

24. Xue L, Greisler HP. Biomaterials in the development and future of vascular grafts. J Vasc Surg. 2003;37(2):472-80.

25. Soldani G, Losi P, Bernabei M, Burchielli S, Chiappino D, Kull S, et al. Long term performance of small-diameter vascular grafts made of a 
poly(ether)urethane-polydimethylsiloxane polymeric network. Biomaterials. 2010;31(9):2592-605.

semi-interpenetrating

26. Faries PL, LoGerfo FW, Arora S, Hook S, Pulling MC, Akbari CM, et al. A comparative study of alternative conduits for lower extremity revascularization: All-autogenous conduit versus prosthetic grafts. J Vasc Surg. 2000;32(6):1080-90.

27. Enomoto S, Sumi $M$, Kajimoto $K$, Nakazawa $Y$, Takahashi $R$, Takabayashi $\mathrm{C}$, et al. Long-term patency of small-diameter vascular graft made from fibroin, a silk-based biodegradable material. J Vasc Surg . 2010;51(1):155-64.

28. Soyer $T$, Lempinen $M$, Cooper $P$, Norton $L$, Eiseman B. A new venous prosthesis. Surgery. 1972;72(6):864-72.

29. Hölzenbein TJ, Pomposelli FB, Miller A, Contreras MA, Gibbons GW, Campbell DR, et al. Results of a policy with arm veins used as the first alternative to an unavailable ipsilateral greater saphenous vein for infrainguinal bypass. J Vasc Surg. 1996;23(1):130-40.

30. Quiñones-Baldrich WJ, Prego AA, Ucelay-Gomez R, Freischlag JA, Ahn SS, Baker JD, et al. Long-term results of infrainguinal revascularization with polytetrafluoroethylene: a ten-year experience. $J$ Vasc Surg. 1992;16(2):209-17.

31. Rutherford RB, Jones DN, Bergentz SE, Bergqvist D, Comerota AJ, Dardik $\mathrm{H}$, et al. Factors affecting the patency of infrainguinal bypass. $J$ Vasc Surg. 1988;8(3):236-46.

32. Quiñones-Baldrich WJ, Busuttil RW, Baker JD, Vescera CL, Ahn SS, Machleder $\mathrm{HI}$, et al. Is the preferential use of polytetrafluoroethylene grafts for femoropopliteal bypass justified? J Vasc Surg. 1988;8(3):219-28.

33. Green RM, Abbott WM, Matsumoto T, Wheeler JR, Miller N, Veith FJ, et al. Prosthetic above-knee femoropopliteal bypass grafting: five-year results of a randomized trial. J Vasc Surg. 2000;31(3):417-25.

34. Abbott WM, Green RM, Matsumoto T, Wheeler JR, Miller N, Veith FJ, et al. Prosthetic above-knee femoropopliteal bypass grafting: results of a multicenter randomized prospective trial. Above-Knee Femoropopliteal Study Group. J Vasc Surg. 1997;25(1):19-28.

35. Van Det RJ, Vriens BHR, van der Palen J, Geelkerken RH. Dacron or ePTFE for femoro-popliteal above-knee bypass grafting: short- and 
long-term results of a multicentre randomised trial. Eur $J$ Vasc Endovasc Surg. 2009;37(4):457-63.

36. Patterson RB, Fowl RJ, Kempczinski RF, Gewirtz R, Shukla R. Preferential use of EPTFE for above-knee femoropopliteal bypass grafts. Ann Vasc Surg. 1990;4(4):338-43.

37. Prendiville EJ, Yeager A, O'Donnell TF, Coleman JC, Jaworek A, Callow $A D$, et al. Long-term results with the above-knee popliteal expanded polytetrafluoroethylene graft. J Vasc Surg. 1990;11(4):51724.

38. Chang BB, Darling RC, Bock DE, Shah DM, Leather RP. The use of spliced vein bypasses for infrainguinal arterial reconstruction. $J$ Vasc Surg. 1995;21(3):403-10.

39. Gentile AT, Lee RW, Moneta GL, Taylor LM, Edwards JM, Porter JM. Results of bypass to the popliteal and tibial arteries with alternative sources of autogenous vein. J Vasc Surg. 1996;23(2):272-9.

40. Hasson JE, Newton WD, Waltman AC, Fallon JT, Brewster DC, Darling $\mathrm{RC}$, et al. Mural degeneration in the glutaraldehyde-tanned umbilical vein graft: incidence and implications. J Vasc Surg. 1986;4(3):243-50.

41. Londrey GL, Bosher LP, Brown PW, Stoneburner FD, Pancoast JW, Davis RK. Infrainguinal reconstruction with arm vein, lesser saphenous vein, and remnants of greater saphenous vein: a report of 257 cases. $J$ Vasc Surg. 1994;20(3):451-6.

42. White RA, Klein SR, Shors EC. Preservation of compliance in a small diameter microporous, silicone rubber vascular prosthesis. J Cardiovasc Surg. 1987;28(5):485-90.

43. Nordestgaard AG, Buckels JA, Wilson SE. Platelet antagonists eliminate thromboembolic complications of small-diameter arterial prostheses. J Vasc Surg. 1987;5(1):110-7.

44. Stimpson C, White R, Klein S, Shors E. Patency and durability of small diameter silicone rubber vascular prostheses. Biomater Artif Cells Artif Organs. 1989;17(1):31-43.

45. Black RA, How T V. Attenuation of flow disturbances in tapered arterial grafts. J Biomech Eng. 1989;111(4):303-10.

46. Lumsden AB, Chen C, Coyle KA, Ofenloch JC, Wang JH, Yasuda HK, et al. Nonporous silicone polymer coating of expanded 
polytetrafluoroethylene grafts reduces graft neointimal hyperplasia in dog and baboon models. J Vasc Surg. 1996;24(5):825-33.

47. Shi Q, Rafii S, Wu MH, Wijelath ES, Yu C, Ishida A, et al. Evidence for circulating bone marrow-derived endothelial cells. Blood. 1998;92(2):362-7.

48. Asahara $T$, Takahashi $T$, Masuda $H$, Kalka $C$, Chen $D$, Iwaguro $H$, et al. VEGF contributes to postnatal neovascularization by mobilizing bone marrow-derived endothelial progenitor cells. EMBO J. 1999;18(14):3964-72.

49. Jeong SI, Kwon JH, Lim JI, Cho S-W, Jung Y, Sung WJ, et al. Mechano-active tissue engineering of vascular smooth muscle using pulsatile perfusion bioreactors and elastic PLCL scaffolds. Biomaterials. 2005;26(12):1405-11.

50. Jeong SI, Kim B-S, Lee YM, Ihn KJ, Kim SH, Kim YH. Morphology of elastic poly(L-lactide-co-epsilon-caprolactone) copolymers and in vitro and in vivo degradation behavior of their scaffolds. Biomacromolecules. 2004;5(4):1303-9.

51. Drasler WJ, Wilson GJ, Stenoien MD, Jenson ML, George SA, Dutcher $\mathrm{RG}$, et al. A spun elastomeric graft for dialysis access. ASAIO J. 1993;39(2):114-9.

52. Hiratzka LF, Goeken JA, White RA, Wright CB. In vivo comparison of replamineform, Silastic, and bioelectric polyurethane arterial grafts. Arch Surg. 1979;114(6):698-702.

53. Robinson TC, inventor; Thoratec Laboratories Corporation, assignee. Arterial graft prothesis. United States patent 4731073. 1988 Mar 15.

54. Shors EC, inventor; Interpore International, assignee. Vascular graft prosthesis and method of making the same. United States patent 4969896. 1990 Nov 13.

55. Whalen RL, inventor; Whalen Biomedical Inc., assignee. Vascular prosthesis having enhanced compatibility and compliance characteristics. United States patent 5354329. 1994 Oct 11.

56. Whalen RL, Cardona RR, Kantrowitz A. A new, all silicone rubber small vessel prosthesis. ASAIO J. 1992;38(3):M207-12. 
57. Bass A, Krupski WC, Hanson SR, Dodson T, Lumsden A, White D, et al. Exteriorized chronic aorto-caval arteriovenous access shunts in the baboon (Papio cynocephalus). J Med Primatol. 1993;22(6):331-9.

58. Farrar DJ. Development of a prosthetic coronary artery bypass graft. Heart Surg Forum. 2000;3(1):36-40.

59. Soldani G, Bernabei M, Losi P, Crucean A, Chiappino D, Burchielli S, et al. In vitro experiments and in vivo implants to evaluate a new silicone-based polyurethane material for replacement of small vessels. Cardiol Young. 2004;14 Suppl 3:20-3.

60. Larena-Avellaneda A, Dittmann G, Haacke C, Graunke F, Siegel R, Dietz UA, et al. Silicone-based vascular prosthesis: assessment of the mechanical properties. Ann Vasc Surg. 2008;22(1):106-14.

61. Holohan AT, George MH, Barrie JA, Parker DG. Polyhydroxyetherpolydimethylsiloxane graft copolymers: 2. Properties and morphology. Polymer. 1994;35(5):977-82.

62. Martin DJ, Poole Warren LA, Gunatillake PA, McCarthy SJ, Meijs GF, Schindhelm K. Polydimethylsiloxane/polyether-mixed macrodiol-based polyurethane elastomers: biostability. Biomaterials. 2000;21(10):10219.

63. Kreiner CF. Chemical and physical aspects of clinically applied silicones. Dev Ophthalmol. 1987;14:11-9.

64. Briganti E, Losi P, Raffi A, Scoccianti M, Munaò A, Soldani G. Silicone based polyurethane materials: a promising biocompatible elastomeric formulation for cardiovascular applications. J Mater Sci Mater Med. 2006;17(3):259-66.

65. Brasil. Ministério da Ciência, Tecnologia e Inovação. Conselho Nacional de Controle de Experimentação Animal. Diretriz brasileira para o cuidado e a utilização de animais para fins científicos e didáticos - DBCA [on-line]. Brasília(DF): Ministério da Ciência, Tecnologia e Inovação; 2013. Disponível em: http://www.cobea.org.br/arquivo/download?ID_ARQUIVO=20

66. De Luccia N, De Luccia TPB. Prótese vascular feita em silicone. Brasil; BR n. PI 0704867-0. 200718 jun. Rev Propriedade industrial (Rio de Janeiro). $200910 \mathrm{fev}$ (1988).

67. Fonseca NM, Goldenberg S, Gomes PO, de Paula Lima CA. Anestesia em coelhos. Acta Cirúrgica Bras. 1996;11(2):82-104. 
68. Ribas LM. Implante experimental de substituto arterial de polidimetilsiloxano com reforço de tecido de poliéster em coelhos [tese]. São Paulo: Faculdade de Medicina, Universidade de São Paulo; 2013.

69. Davies MG, Hagen PO. Pathophysiology of vein graft failure: a review. Eur J Vasc Endovasc Surg. 1995;9(1):7-18.

70. Thomas a, Campbell G, Campbell J. Advances in vascular tissue engineering. Cardiovasc Pathol. 2003;12(5):271-6.

71. Bos GW, Poot AA, Beugeling T, van Aken WG, Feijen J. Smalldiameter vascular graft prostheses: current status. Arch Physiol Biochem. 1998;106(2):100-15.

72. Allaire E, Clowes AW. Endothelial cell injury in cardiovascular surgery: the intimal hyperplastic response. Ann Thorac Surg. 1997;63(2):58291.

73. Osgood MJ, Hocking KM, Voskresensky I V, Li FD, Komalavilas P, Cheung-Flynn J, et al. Surgical vein graft preparation promotes cellular dysfunction, oxidative stress, and intimal hyperplasia in human saphenous vein. J Vasc Surg. In press 2013. doi: 10.1016/j.jvs.2013.06.004

74. United States Food and Drug Administration. Guidance Documents (Medical Devices and Radiation-Emitting Products) - Guidance for Industry and FDA Staff: Guidance Document for Vascular Prostheses 510(k) Submissions [on-line]. U.S. FDA;2000.Disponível em: http://www.fda.gov/MedicalDevices/DeviceRegulationandGuidance/Gui danceDocuments/ucm073681.htm

75. Campbell CD, Goldfarb D, Roe R. A small arterial substitute: expanded microporous polytetrafluoroethylene: patency versus porosity. Ann Surg. 1975;182(2):138-43.

76. Brophy CM, Ito RK, Quist WC, Rosenblatt MS, Contreras M, Tsoukas $\mathrm{A}$, et al. A new canine model for evaluating blood prosthetic arterial graft interactions. J Biomed Mater Res. 1991;25(8):1031-8.

77. Swartz D, Andreadis S. Animal models for vascular tissue-engineering. Curr Opin Biotechnol; 2013;24(5):916-25.

78. Crotaz IR. An observational clinical study in cats and rabbits of an anatomically designed supraglottic airway device for use in companion animal veterinary anaesthesia. Vet Rec. 2013;172(23):606. 
79. Grint N. How to...Approach rabbit anaesthesia with confidence. J Small Anim Pract. 2009;50(11):12-6.

80. Loh S a, Howell BS, Rockman CB, Cayne NS, Adelman M a, Gulkarov I, et al. Mid- and Long-Term Results of the Treatment of Infrainguinal Arterial Occlusive Disease With Precuffed Expanded Polytetrafluoroethylene Grafts Compared With Vein Grafts. Ann Vasc Surg. 2013;27(2):208-17.

81. Matsuyama K, Chiba Y, Ihaya A, Kimura T, Tanigawa N, Muraoka R. Effect of spinal cord preconditioning on paraplegia during crossclamping of the thoracic aorta. Ann Thorac Surg. 1997;63(5):1315-20.

82. Wisselink W, Money SR, Crockett DE, Nguyen JH, Becker MO, Farr $\mathrm{GH}$, et al. Ischemia-reperfusion injury of the spinal cord: protective effect of the hydroxyl radical scavenger dimethylthiourea. $J$ Vasc Surg. 1994;20(3):444-91.

83. Papanastasiou S, Estdale SE, Homer-Vanniasinkam S, Mathie RT. Protective effect of preconditioning and adenosine pretreatment in experimental skeletal muscle reperfusion injury. $\mathrm{Br} J$ Surg. 1999;86(7):916-22.

84. Sakurai M, Hayashi T, Abe K, Aoki M, Sadahiro M, Tabayashi K. Enhancement of heat shock protein expression after transient ischemia in the preconditioned spinal cord of rabbits. $J$ Vasc Surg. 1998;27(4):720-5.

85. Echave V, Koornick AR, Haimov M, Jacobson JH. Intimal hyperplasia as a complication of the use of the polytetrafluoroethylene graft for femoral-popliteal bypass. Surgery. 1979;86(6):791-8.

86. Sterpetti A V, Hunter WJ, Schultz RD, Farina C. Healing of highporosity polytetrafluoroethylene arterial grafts is influenced by the nature of the surrounding tissue. Surgery. 1992;111(6):677-82.

87. Sottiurai VS, Yao JS, Flinn WR, Batson RC. Intimal hyperplasia and neointima: An ultrastructural analysis of thrombosed grafts in humans. Surgery. 1983;93(6):809-17.

88. Cox JL, Chiasson DA, Gotlieb Al. Stranger in a strange land: the pathogenesis of saphenous vein graft stenosis with emphasis on structural and functional differences between veins and arteries. Prog Cardiovasc Dis. 1991;34(1):45-68. 
89. Sauvage LR, Berger KE, Wood SJ, Yates SG, Smith JC, Mansfield PB. Interspecies healing of porous arterial prostheses: observations, 1960 to 1974. Arch Surg. 1974;109(5):698-705.

90. Brandão ML, Coutinho Netto J, Thomazini JA, Lachat JJ, Muglia VF, Piccinato CE. Prótese vascular derivada do látex. J Vasc Bras. 2007;6(2):130-41.

91. Zilla P, Bezuidenhout D, Human P. Prosthetic vascular grafts: wrong models, wrong questions and no healing. Biomaterials. 2007;28(34):5009-27.

92. Niklason LE. Techview: medical technology. Replacement arteries made to order. Science. 1999;286(5444):1493-4. 